\title{
Geologic Map of the Harvard Lakes 7.5' Quadrangle, Park and Chaffee Counties, Colorado
}

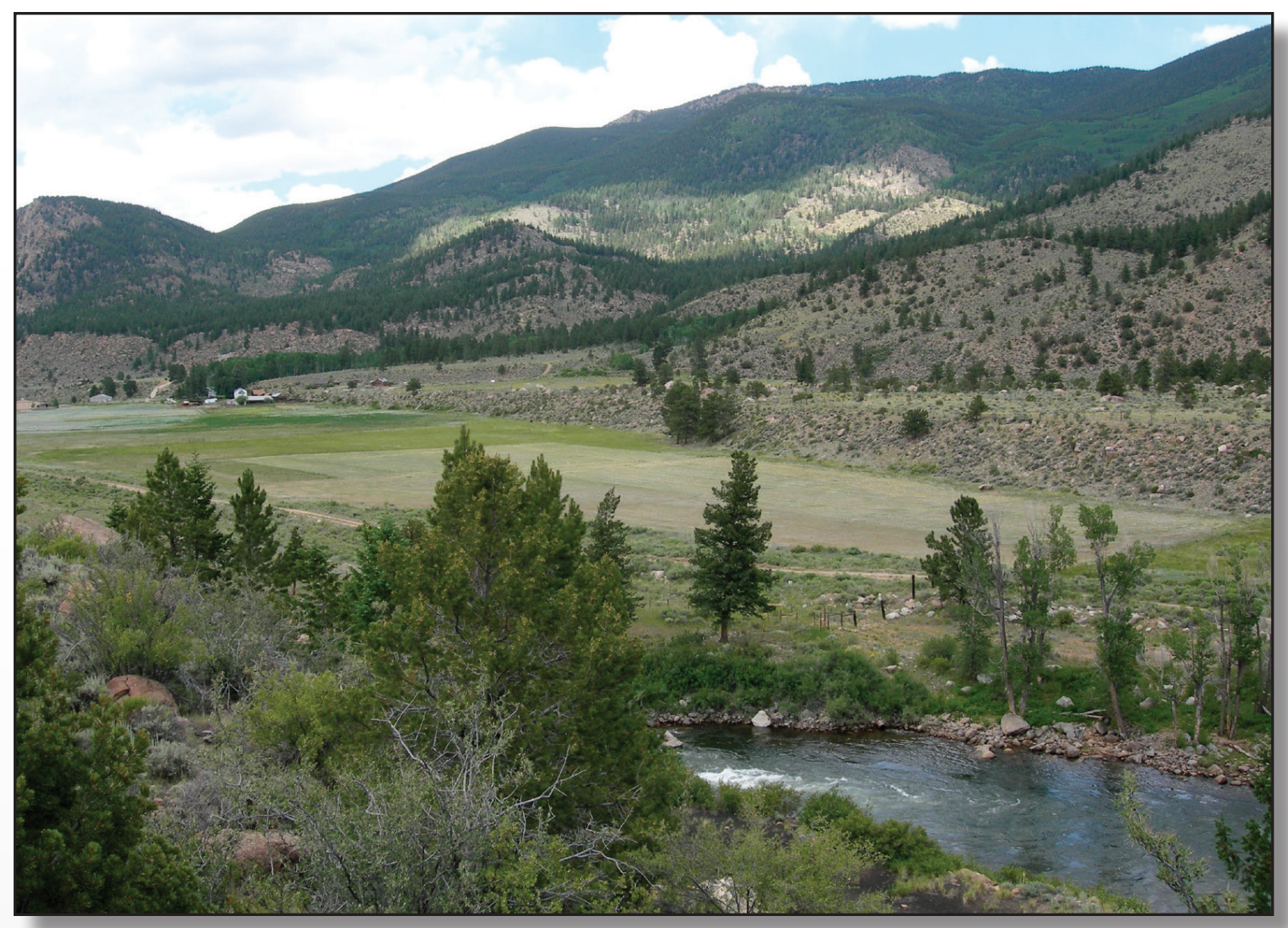

Pamphlet to accompany

Scientific Investigations Map 3267 
Cover: View to northeast from Highway 24 of terraces along Arkansas River, Chaffee County, Colorado. Photograph by K.S. Kellogg. 


\section{Geologic map of the Harvard Lakes 7.5' Quadrangle, Park and Chaffee Counties, Colorado}

By Karl S. Kellogg, Keenan Lee, Wayne R. Premo, and Michael A. Cosca

Pamphlet to accompany

Scientific Investigations Map 3267 


\title{
U.S. Department of the Interior SALLY JEWELL, Secretary
}

\section{U.S. Geological Survey Suzette M. Kimball, Acting Director}

\author{
U.S. Geological Survey, Reston, Virginia: 2013
}

For more information on the USGS - the Federal source for science about the Earth, its natural and living resources, natural hazards, and the environment, visit http://www.usgs.gov or call 1-888-ASK-USGS.

For an overview of USGS information products, including maps, imagery, and publications, visit http://www.usgs.gov/pubprod

To order this and other USGS information products, visit http://store.usgs.gov

Any use of trade, firm, or product names is for descriptive purposes only and does not imply endorsement by the U.S. Government.

Although this information product, for the most part, is in the public domain, it also may contain copyrighted materials as noted in the text. Permission to reproduce copyrighted items must be secured from the copyright owner.

Suggested citation:

Kellogg, K.S., Lee, Keenan, Premo, W.R., and Cosca, M.A., 2013, Geologic map of the Harvard Lakes 7.5' quadrangle, Park and Chaffee Counties, Colorado: U.S. Geological Survey Scientific Investigations Map 3267, 22 p., scale 1;24,000, http://dx.doi.org/10.3133/sim3267.

ISSN 2329-132X (online) 


\section{Contents}

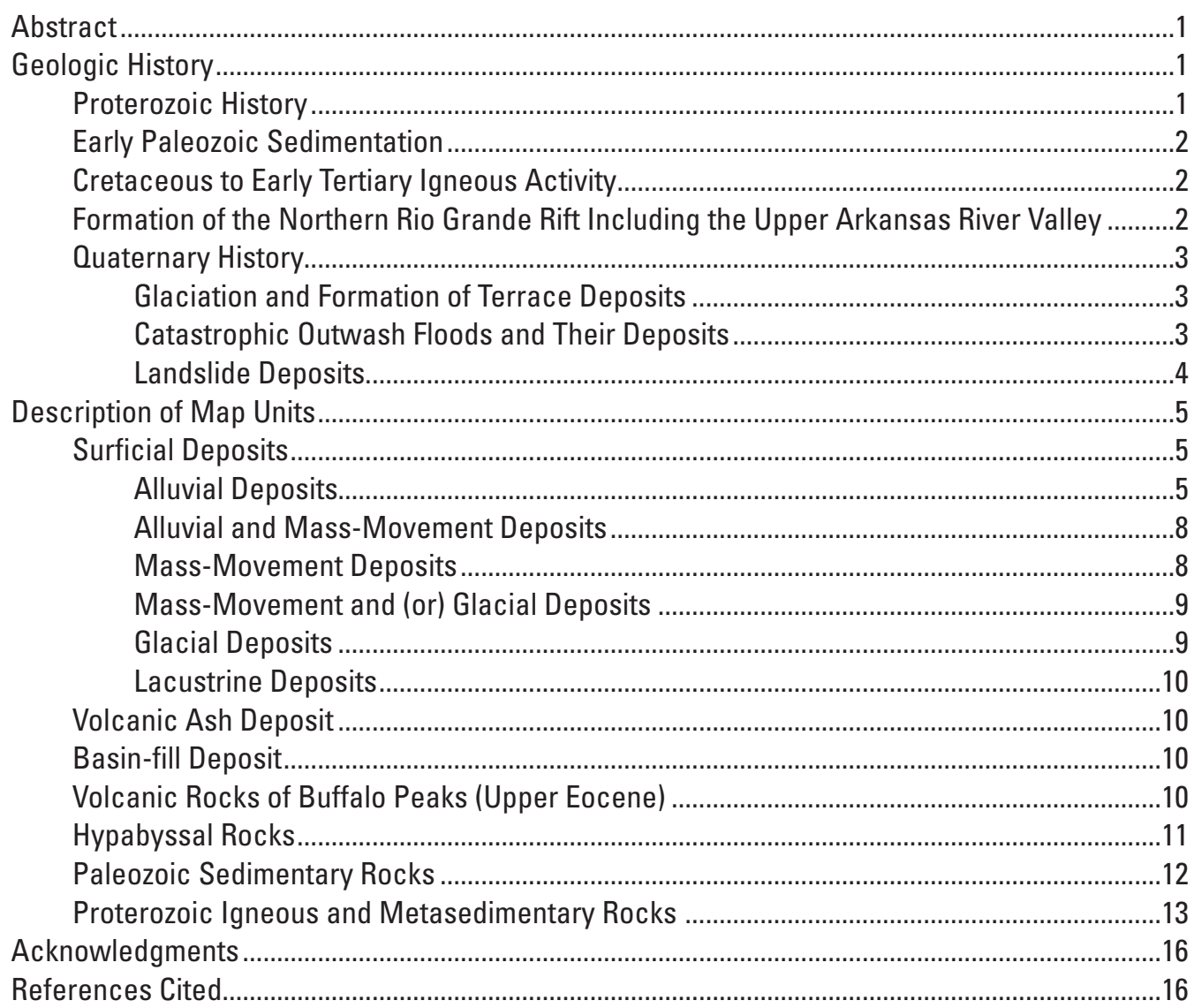

\section{Sheet}

Geologic map of the Harvard Lakes 7.5' quadrangle, Park and Chaffee

Counties, Colorado.

\section{Figures}

1. A, Enormous granitic flood boulder on Qpo terrace. $B$, The largest flood boulder known in the Arkansas Valley, on Qpoo terrace ................................................6

2. View to northeast from Highway 24 of terraces along Arkansas River...............................7

3. View to north of $50-\mathrm{cm}$-thick air-fall ash interpreted to be Lava Creek B ash (Qaa), erupted from the Yellowstone region $639 \pm 2 \mathrm{ka}$

4. A, Contact of granite of Langhoff Gulch (Ygl) intruding weakly foliated granite of Elephant Rock (Yge). B, Inclusion of granite of Elephant rock (Yge) enclosed in granite of Langhoff gulch (Ygl)

5. Strongly foliated augen gneiss formed from highly strained granite of Elephant Rock (Yge)

\section{Table}

1. New isotopic dates determined for Harvard Lakes quadrangle 


\section{Conversion Factors}

Inch/Pound to SI

\begin{tabular}{lcl}
\hline Multiply & By & To obtain \\
\hline & Length & \\
\hline inch (in.) & 2.54 & centimeter $(\mathrm{cm})$ \\
inch (in.) & 25.4 & millimeter $(\mathrm{mm})$ \\
foot (ft) & 0.3048 & meter $(\mathrm{m})$ \\
mile (mi) & 1.609 & kilometer $(\mathrm{km})$ \\
\hline & Mass & \\
\hline ton & 0.9072 & metric ton \\
\hline
\end{tabular}

SI to Inch/Pound

\begin{tabular}{lcl}
\hline Multiply & By & To obtain \\
\hline & Length & \\
\hline centimeter $(\mathrm{cm})$ & 0.3937 & inch (in.) \\
meter $(\mathrm{m})$ & 3.281 & foot (ft) \\
kilometer $(\mathrm{km})$ & 0.6214 & mile (mi) \\
\hline & Mass & \\
\hline metric ton & 1.102 & tons \\
\hline
\end{tabular}

Vertical coordinate information is referenced to National Geodetic Vertical Datum of 1929.

Horizontal coordinate information is referenced to North American Datum of 1927 (NAD 27).

\section{Division of Quaternary, Neogene, and Paleogene Time Used in This Report ${ }^{1}$}

\begin{tabular}{cllc}
\hline Period or subperiod & Epoch & \multicolumn{1}{c}{ Age } \\
\hline \multirow{2}{*}{ Quaternary } & Holocene & & $0-11.7 \mathrm{ka}$ \\
& & Late & $11.7-132 \mathrm{ka}$ \\
& Pleistocene & middle & $132-788 \mathrm{ka}$ \\
Neogene & & early & $788 \mathrm{ka}-2.58 \mathrm{Ma}$ \\
& Pleistocene & & $2.58-5.33 \mathrm{Ma}$ \\
& Miocene & & $5.33-23.0 \mathrm{Ma}$ \\
& Oligocene & & $23.0-33.9 \mathrm{Ma}$ \\
Paleogene & Eocene & & $33.9-55.8 \mathrm{Ma}$ \\
& Paleogene & $55.8-65.5 \mathrm{Ma}$ \\
\hline
\end{tabular}

${ }^{1}$ Ages of time boundaries are those of the U.S. Geological Survey Geologic Names Committee (2009).

$\mathrm{Ka}$, thousand years; Ma, million years; m.y., millions of years. 


\title{
Geologic Map of the Harvard Lakes 7.5' Quadrangle, Park and Chaffee Counties, Colorado
}

\author{
By Karl S. Kellogg, ${ }^{1}$ Keenan Lee, ${ }^{2}$ Wayne R. Premo, ${ }^{1}$ and Michael A. Cosca ${ }^{1}$
}

\section{Abstract}

The Harvard Lakes 1:24,000-scale quadrangle spans the Arkansas River valley in central Colorado, and includes the foothills of the Sawatch Range on the west and Mosquito Range on the east. The Arkansas River valley lies in the northern end of the Rio Grande rift and is structurally controlled by Oligocene and younger normal faults mostly along the west side of the valley. Five separate pediment surfaces were mapped, and distinctions were made between terraces formed by the Arkansas River and surfaces that formed from erosion and alluviation that emanated from the Sawatch Range. Four flood deposits containing boulders as long as $15 \mathrm{~m}$ were deposited from glacial breakouts just north of the quadrangle. Miocene and Pliocene basin-fill deposits of the Dry Union Formation are exposed beneath terrace or pediment deposits in several places. The southwestern part of the late Eocene Buffalo Peaks volcanic center, mostly andesitic breccias and flows and ash-flow tuffs, occupy the northeastern corner of the map. Dated Tertiary intrusive rocks include Late Cretaceous or early Paleocene hornblende gabbro and hornblende monzite. Numerous rhyolite and dacite dikes of inferred early Tertiary or Late Cretaceous age also intrude the basement rocks.

Basement rocks are predominantly Mesoproterozoic granites, and subordinately Paleoproterozoic biotite gneiss and granodiorite.

\section{Geologic History}

This research was supported by the National Cooperative Geologic Mapping Program of the U.S. Geological Survey (USGS). The Harvard Lakes quadrangle spans the upper Arkansas River valley, which is structurally controlled by faults within a north-northwest-trending graben that is the northern part of the Rio Grande rift. The rift is a zone of crustal extension containing normal faults that extends south as far as Mexico (Chapin, 1979) and north as far as southern Wyoming (Tweto, 1979; Mears, 1998). Paleoproterozoic rocks

${ }^{1}$ U.S. Geological Survey

${ }^{2}$ Colorado School of Mines, Professor Emeritus as old as about 1,780 Ma are exposed on both sides of the valley, as well as early Paleozoic quartzite and dolomite. The Eocene volcanic rocks of the Buffalo Peaks volcanic center (Hedlund, 1985) crop out in the northeastern corner of the quadrangle. The array of terrace deposits exposed mostly on the western side of the valley was derived from two sources: (1) tributary valleys flowing east out of the Sawatch Range, and (2) the Arkansas River itself. Glaciers flowing out of the Sawatch Range deposited large moraines of at least three major glacial episodes along Powell Creek, Three Elk Creek, Frenchman Creek, and Pine Creek.

The geologic history of the quadrangle, therefore, can be divided into five major chapters: (1) Proterozoic history, (2) early Paleozoic sedimentation, (3) Cretaceous to early Tertiary igneous activity, (4) formation of the northern Rio Grande rift and the upper Arkansas River valley, and (5) Quaternary history.

\section{Proterozoic History}

Marine sediments and mafic and felsic volcanic rocks were deposited locally in the central Rocky Mountain region (including the map area) between about 1,780 and 1,740 Ma (Premo and others, 2007). They were generally metamorphosed to amphibolite grade, and intruded and deformed by mostly calc-alkalic granitic rocks during a long orogenic episode that lasted about 110 m.y. These rocks, mapped as biotite gneiss and minor amphibolite, are part of a Paleoproterozoic terrane called the Colorado province (Bickford and others, 1986). The Colorado province is generally interpreted to have formed following accretion of island arcs and back-arc basins to the southern margin of the Wyoming craton, which marks the southern edge of the Archean continent of Laurentia (Reed and others, 1993; Aleinikoff and others, 1993; Chamberlain, 1998). Chamberlain (1998) calls this 1,780-1,740 Ma suturing event the Medicine Bow orogeny. Recent alternative models argue that island arc rocks are not present in the Colorado province and that the rocks were derived from extension of pre-existing crust of an unknown age (Hill and Bickford, 2001; Bickford and Hill, 2007; Bickford and others, 2008; DeWitt and others, 2010). 
Zircons from biotite gneiss from the Front Range region to the northeast and the Blue River valley region to the north are 1,785-1,740 Ma (Kellogg and others, 2008, 2011; W.R. Premo, USGS, written commun., 2008), which is the age of the zircons derived from source rock and represents the maximum age of deposition. Similar rocks in the Salida region, about $25 \mathrm{~km}$ south of the quadrangle, have zircon ages of about 1,730 Ma (W.R. Premo, USGS, written commun., 2011), which is the metamorphic age of the rocks.

Following the approximate 1,750-1,730 Ma period of metamorphism, extensive batholiths and smaller bodies of mostly granodiorite and monzogranite, referred to as the Paleoproterozoic Routt Plutonic Suite (Tweto, 1987), intruded the older layered rocks. A granodiorite body (Xgd), tentatively correlated with the Denny Creek Granodiorite pluton immediately to the west in the Mount Harvard quadrangle (Brock and Barker, 1972; Fridrich and others, 1998), underlies a large area in the western part of the quadrangle. Zircon ages for the Denny Creek are somewhat ambiguous (W.R. Premo, USGS, written commun., 2011), but suggest an age of about 1,685 Ma.

By far the most voluminous intrusive rocks in the quadrangle are granitic rocks of the Mesoproterozoic Berthoud Plutonic Suite of Tweto (1987). These rocks include the 1,438 \pm 7 Ma granite of Elephant Rock (Yge) and the slightly younger, 1,446 \pm 50 Ma granite of Langhoff Gulch (Ygl), both of which have identical ages within experimental uncertainty. The granite of Elephant Rock was either molten or relatively ductile when the granite of Langhoff Gulch intruded, and contact zones are commonly gradational; a hybrid zone (Yhy) is mapped where the two are intermingled. Locally, the granite of Elephant Rock is moderately to strongly foliated, with foliation striking generally east and dipping north.

\section{Early Paleozoic Sedimentation}

A small exposure of Cambrian and Ordovician rocks is exposed in the northeastern corner of the quadrangle, overlain by the volcanic rocks of the Buffalo Peaks. The basal Upper Cambrian Sawatch Quartzite and Dotsero Formation consist of quartz sandstone that was deposited in a near-shore environment. Worm burrows are prominently displayed in some of these rocks. The Sawatch is overlain by mostly dolomitic rocks of the marine Ordovician Manitou Formation. No non-Tertiary sedimentary rocks younger than Ordovician are exposed in the quadrangle, but a thick section of such rocks are exposed immediately to the east (Widmann and others, 2011; Houck and others, 2012).

\section{Cretaceous to Early Tertiary Igneous Activity}

Numerous dikes and small intrusive stocks intrude the older rocks in the quadrangle. Dacite and rhyolite dikes, the latter quartz phyrric in places, are the most numerous and may be as old as Late Cretaceous, based on one Late Cretaceous potassium-argon age of $65.3 \pm 2.4 \mathrm{Ma}$ from a quartz rhyolite dike $5 \mathrm{~km}$ north of the quadrangle (Marvin and others, 1989). One dacite stock, approximately $1 \mathrm{~km}$ long, is in the southeastern corner of the quadrangle. Several mines and prospects appear to be associated with some of the dacitic rocks. A cluster of small Late Cretaceous (68.1 $\pm 0.9 \mathrm{Ma})$ gabbro stocks along and near Buffalo Creek, east of the Arkansas River, hosted a low-grade sulfide deposit. A 65.3 \pm 0.3 Ma monzodiorite stock and cogenetic dike crop out near Morrison Creek, west of the Arkansas River. The late Eocene Buffalo Peak volcanic center includes andesite flows and breccias, and interbedded tuffs. Enigmatic andesitic intrusive bodies just south of the (informally named) Buffalo Peaks (units PEbn and Peai) may be feeders for at least some of the volcanic rocks. $\mathrm{A}^{40} \mathrm{Ar} /{ }^{39} \mathrm{Ar}$ age of $38.18 \pm 0.32 \mathrm{Ma}$ was measured from an ash-flow tuff from the Buffalo Peaks volcanic center (McIntosh and Chapin, 2004), in agreement with a new ${ }^{40} \mathrm{Ar} /{ }^{39} \mathrm{Ar}$ age on hornblende of $37.9 \pm 0.3 \mathrm{Ma}$ (sample HL09-170, location D, table 1) from a lower ashflow tuff.

The numerous small stocks and dikes intruded during the Laramide orogeny, a Late Cretaceous to Eocene period of contractional tectonism and mountain building. Laramide structural features, such as thrust and reverse faults, have not been documented in the Harvard Lakes quadrangle, but are regionally common (for example, Tweto, 1975; Kellogg and others, 2004).

\section{Formation of the Northern Rio Grande Rift Including the Upper Arkansas River Valley}

Numerous, mostly down-to-the-east normal faults bound the west side of the valley and are the result of crustal extension that probably began during the Oligocene and are characteristic of the northern Rio Grande rift. The oldest dated volcanic rocks interbedded with syn-rift sedimentary deposits are $26 \mathrm{Ma}$ or Oligocene (Thompson and others, 1991; Chapin and Cather, 1994), and mark the approximate time of initial rifting. A few down-to-the-west normal faults also cut the rocks on the east side of the valley, but the preponderance of down-to-the-east large faults on the west side of the valley indicated that the units underlying the valley have progressively tilted to the west. The age of the faulting is not well constrained and most scarps are highly degraded, indicating that last faulting in the area may be at least as 
old as late Pleistocene. No historic earthquakes have been reported for this portion of the Arkansas River Valley; in fact, the entire Rio Grande Rift region is remarkable aseismic (for example, Sanford and others, 1979). Whether this means that the existing faults are "locked" and potentially building stress, or whether the regional extensional stresses have relaxed during the Holocene and possibly late Pleistocene is unknown.

The valley within the Harvard Lakes quadrangle is underlain in places by at least several hundred meters of Miocene and Pliocene basin fill, the Dry Union Formation. These deposits consist of locally tuffaceous siltstone, sandstone, and conglomerate and were deposited during a period of widespread intermontane basin filling that is contemporaneous, in part, with the Santa Fe, Troublesome, Browns Park, North Park, and Arikaree Formations in adjacent or nearby basins (Izett, 1968; Kellogg and others, 2011).

\section{Quaternary History}

\section{Glaciation and Formation of Terrace Deposits}

Although the Arkansas River valley is not glaciated, large glaciers flowed down the Three Elk, Frenchman, and Pine Creek drainages from the Sawatch Range to the west and deposited extensive moraine complexes. Deposits interpreted as pre-Bull Lake (Scott, 1975) lie just south of the mouth of Frenchman Creek; these deposits may be as old as early Pleistocene. Bull Lake glacial deposits, approximately 165-120 ka (Licciardi and Pierce, 2008; Schildgen and others, 2002; Shroba and others, 1983), are mapped in a few places. Most glacial deposits are from the Pinedale glaciation (about 30-12 ka; Nelson and others, 1979; Madole, 1986; Benson and others, 2004, 2005; and additional references listed under description for till of Pinedale glaciation, Qtp); compared to older till deposits, Pinedale-age moraines have sharper crests and more hummocky topography.

Terrace deposits as old as early Pleistocene were deposited both along tributary creeks to the Arkansas River and by the Arkansas River itself; we have made an attempt to differentiate deposits from the two different sources. The terraces formed during periods of increased alluviation, and at least the most recent (topographically lowest) terraces formed during middle to late Pleistocene glacial periods; these terraces are underlain by outwash gravels from these glaciers. Several terraces, such as Qg2 and Qg3, each contain small terrace risers indicating multiple terraces of slightly different ages that are not differentiated on the map. In addition, abandoned channels of the Arkansas River are mapped in the two youngest, Pinedale-age terraces of the Arkansas River.

\section{Catastrophic Outwash Floods and Their Deposits}

At least three flood deposits are recognized, all of which are most likely the result of breakout floods from glacial dams at the mouth of Clear Creek, although glacial-dam breakouts at the mouth of Pine Creek (refer to structure map on map sheet) may also have contributed to large floods. Glaciers that flowed down Clear Creek and Pine Creek during both Bull Lake and Pinedale glaciations, and probably during earlier glaciations, crossed the Arkansas River channel and ran into the steep granite wall on the east side of the valley, causing the glaciers to thicken, merge, and form large glacial dams that impounded the Arkansas River. The glacial lakes that formed above these dams were on the order of $200 \mathrm{~m}$ deep and $18 \mathrm{~km}$ long based on estimated heights $(200 \mathrm{~m}$ ) of the glacial dams (Lee, 2010). Each time the ice dam failed, the glacial lake emptied almost instantly and catastrophically. The surging floodwaters tore out the distal portions of the end moraines, as well as large granitic blocks from the eastern valley wall, and carried the debris downstream.

The first recognized flood coursed down a relatively broad, flat valley more than $639 \mathrm{ka}$, the age of the Lava Creek B ash (Lanphere and others, 2002), which caps a gravel (Qao) containing huge boulders (some larger than $6 \mathrm{~m}$ ) that were deposited by the flood.

Although the Bull Lake moraines of both Clear Creek and Pine Creek indicate the Bull Lake glaciers were at least as large as the Pinedale glaciers and similarly dammed the Arkansas River (Lee, 2010), no clear evidence of a Bull Lake flood exists in this part of the valley. No Bull Lake terraces are recognized along the Arkansas River in the map area, although Bull Lake terraces are recognized both to the north (McCalpin and others, 2012) and to the south (Scott, 1975).

At least two breakout floods during the Pinedale glaciation are recognized. Boulders of the older of these floods deposits (Qpoo) are as long as $15 \mathrm{~m}$ and lie on a terrace about $25 \mathrm{~m}$ above the river; these boulders have beryllium-10 $\left({ }^{10} \mathrm{Be}\right)$ surface-exposure ages of about 19.2 $\pm 0.1 \mathrm{ka}$ (Young and others, 2011). This older flood may have undercut the rightlateral Pine Creek moraines, creating slope instability and slumping of the Pine Creek School landslide. This landslide is composed almost entirely of till of the Bull lake glaciation. Following deposition of unit Qpoo, the Arkansas River flowed briefly on the east side of the valley against Proterozoic rock, producing channel deposits (Qpooc), south of Tumble Creek.

A distinctive flood deposit (Qfa) that is probably part of the older outwash deposit of the Pinedale glaciation (Qpoo), but is mapped separately, is composed of coarse gravels deposited on the Pine Creek School landslide, which is composed almost entirely of displaced till of the Bull Lake glaciation. These deposits contain distinctive clasts of the Paleocene Twin Lakes porphyry pluton from the Sawatch 
Range (Fridrich and others, 1998) that were carried as suspension load as high as $59 \mathrm{~m}$ above the present Arkansas River (Lee, 2010).

The last recognized breakout flood eroded a new channel and outwash plain about $18 \mathrm{~m}$ below the Qpoo gravel; the youngest terrace gravel (Qpo) composes the surface of this terrace. Surface-exposure ages (from ${ }^{10} \mathrm{Be}$ analysis) from large (as long as about $10 \mathrm{~m}$ ) flood boulders on this terrace are $17.8 \pm 0.6 \mathrm{ka}$ (Young and others, 2011), concurrent with late Pinedale glaciation. The lake that preceded the last breakout flood probably had about the same dimensions as previous lakes because boulders of similar size were deposited. When the ice dam failed, the flood deposited a bedload sheet of stacked boulders in the half-km-wide valley bottom.

Contrary to the interpretations of this report, Lee (2010) suggests that the older, higher of the youngest two surfaces (Qpoo) is Bull Lake age, despite the statistically distinct, about 1,500 year difference in surface-exposure ages from boulders on the two surfaces. In this interpretation: (1) during the interglacial interval between the Bull Lake and Pinedale glaciations, the Arkansas River eroded about $18 \mathrm{~m}$ into the Bull Lake surface (Qpoo in this report), prior to the Pinedale glacial breakout flood that deposited boulders on the Qpo surface, (2) the enormous boulders that were sampled on the higher of the two surfaces are part of an overbank deposit from the flood that deposited the boulders on the Qpo surface, and (3) the high-level gravels containing clasts of Twin Lake porphyry (Qfa) were deposited during the proposed single Pinedale-age flood.

After the last breakout flood that produced the Qpo deposit, the ancestral Arkansas River changed course several times, eventually establishing a channel (Qpoc) against the west side of the valley south of Morrison Creek. The southeast part of the Pine Creek School landslide failed again, diverting the Arkansas River to the east into its present course.

Subsequent alluviation by tributary streams built alluvial fans that buried many areas along the valley margin, which partially obscured some of the terrace and flood relationships.

\section{Landslide Deposits}

Landslide deposits are mapped at many localities, most prominently on the south side of West Buffalo Peak in the northeast corner of the quadrangle, east of Fourmile Creek along the east side of the quadrangle, and in the large Pine Creek School landslide just west of Highway 24 in the north part of the quadrangle. The eastern part of the Pine Creek School landslide, east of the lowest scarp shown on the map, is the most hummocky and probably the most active; numerous closed depressions (some filled by ponds) suggest that this part of the slide may still be active. Numerous smaller landslide deposits are mapped at many locations. 


\title{
DESCRIPTION OF MAP UNITS
}

\section{Surficial Deposits}

\author{
Alluvial Deposits
}

Qa

Qpoc

Qpo

Qpooc

Qfa

Qpoo
Stream-channel and overbank alluvium (Holocene)-Mostly clast-supported pebble, cobble, and boulder gravel in a sandy-silt matrix. Clasts subrounded to well-rounded and consist of Proterozoic igneous and metamorphic rocks, Cretaceous and Tertiary intrusive rocks, and, in Arkansas River channel, Paleozoic sedimentary rocks (mostly Cambrian quartzite). Deposits form low terraces less than about $2 \mathrm{~m}$ above present stream level; prone to infrequent flooding during exceptionally wet years; many tributary streams to the Arkansas River are intermittent. Locally includes some colluvium $(\mathrm{Qc})$ and small fan deposits (Qf). Forms current bed of Arkansas River (where it is too narrow to show on map) and tributary streams. Estimated thickness as much as about $5 \mathrm{~m}$ fill

Channel deposit in younger Pinedale-age outwash deposit (late Pleistocene) - Relatively finer-grained alluvium in channels and swales cut into Pinedale outwash deposits (Qpo) of Arkansas River. Flood boulders are rare or absent. Channels represent courses of ancestral Arkansas River. Estimated thickness as much as $2 \mathrm{~m}$

Younger Pinedale-age flood deposit (late Pleistocene) - Grayish-tan, unstratified alluvium consisting of pebble, cobble, and boulder gravel in a sandy matrix. All mapped units, except one in valley of Pine Creek, were deposited by the Arkansas River during Pinedale-age glaciation. Most clasts less than $2 \mathrm{~m}$ in diameter, but many along valley of Arkansas River are as long as about $5 \mathrm{~m}$, with a maximum observed size of $7.6 \mathrm{~m} \times 6.1 \mathrm{~m}$ $\times 4.1+\mathrm{m}($ fig. $1 \mathrm{~A}$ ) and were deposited during one of several catastrophic breakouts of glacial dams at Clear and Pine Creeks, just north of quadrangle boundary (Lee, 2010). Clasts are almost entirely Proterozoic granitic and gneissic rocks, with a small population of 64-Ma Twin Lakes Granodiorite porphyry derived from either Clear Creek or Lake Creek drainage (Fridrich and others, 1998). ${ }^{10}$ Be surface-exposure ages from large flood boulders on this deposit indicate mean age of $17.8 \pm 0.6 \mathrm{ka}$ (Young and others, 2011). Forms terraces between about 5-8 m above present level of Arkansas River (fig. 2). The large difference (about $18 \mathrm{~m}$ ) between height of this terrace and that of older Pinedale-age outwash deposits (Qpoo) demonstrates significant erosion during younger flood. Estimated thickness as much as $10 \mathrm{~m}$

Channel deposits in older Pinedale-age outwash deposit (late Pleistocene) - Relatively finer-grained alluvium in channels and swales cut into older Pinedale-age outwash deposits (Qpoo) of Arkansas River. One exposure consists of boulder-cobble-pebble gravel on top of flood boulders; sand layer at top. Another exposure shows 5-6 m of fluvial gravel on Dry Union Formation

High-level flood gravel of older Pinedale glaciation (late Pleistocene) - Coarse flood gravel that is exposed in patches along the west margin of the valley, including deposits of Pine Creek School landslide. Deposits are about 2.5-6 m thick, with a median thickness of $4 \mathrm{~m}$, and contain boulders and cobbles as long as about $2 \mathrm{~m}$ of the distinctive 64-Ma Twin Lakes Granodiorite porphyry, which is exposed in the headwaters of Clear Creek and Lake Creek to the north, but not the headwaters of Pine Creek (Fridrich and others, 1998). The pebbles, cobbles, and boulders of the alluvium are clast supported, with an openwork texture now mostly filled by sand, and lack apparent stratification. The highest deposits overlying the Pine Creek School landslide are as much as $57 \mathrm{~m}$ above the present Arkansas River. Deposits overlying the landslide may themselves have slid. The Pine Creek School landslide is composed primarily of till of Bull Lake glaciation from a glacier that flowed down Pine Creek, so these flood gravels must be post-Bull Lake in age. They are interpreted as deposited from bedload and possibly suspension loads during deposition of the older Pinedaleage flood deposits (Qpoo)

Older Pinedale-age flood deposit (late Pleistocene) - Grayish tan, unstratified alluvium deposited by Arkansas River consisting of pebble, cobble, and boulder gravel in a sandy matrix. Interpreted as traction bed load of major flood from breakout of glacial dam at mouth of Clear Creek and (or) Pine Creek, just north of quadrangle. Clasts as long as $14 \mathrm{~m}$ (fig. $1 B$ ) deposited during breakout flood from glacier-dammed Clear and Pine Creeks, just north of quadrangle (Lee, 2010). ${ }^{10} \mathrm{Be}$ surface-exposure ages from large flood boulders on this deposit indicate mean age of 19.2 $\pm 0.1 \mathrm{ka}$ (Young and others, 2011), although interpreted as Bull Lake gravels by Lee (2010). Forms terraces about 15-18 m above present level of Arkansas River, and about 8-12 m above level of younger Pinedale-age outwash deposits (Qpo) (fig. 2). Thickness of gravel is $\geq 19 \mathrm{~m}$ at its northern mapped extent in quadrangle and appears to thin distally to about $5 \mathrm{~m}$ near Elephant Rock, where it overlies Dry Union Formation. Flood boulders are almost always stacked upon each other throughout thickness of unit. Top of older Pinedale-age flood deposits are about $25 \mathrm{~m}$ above river level 

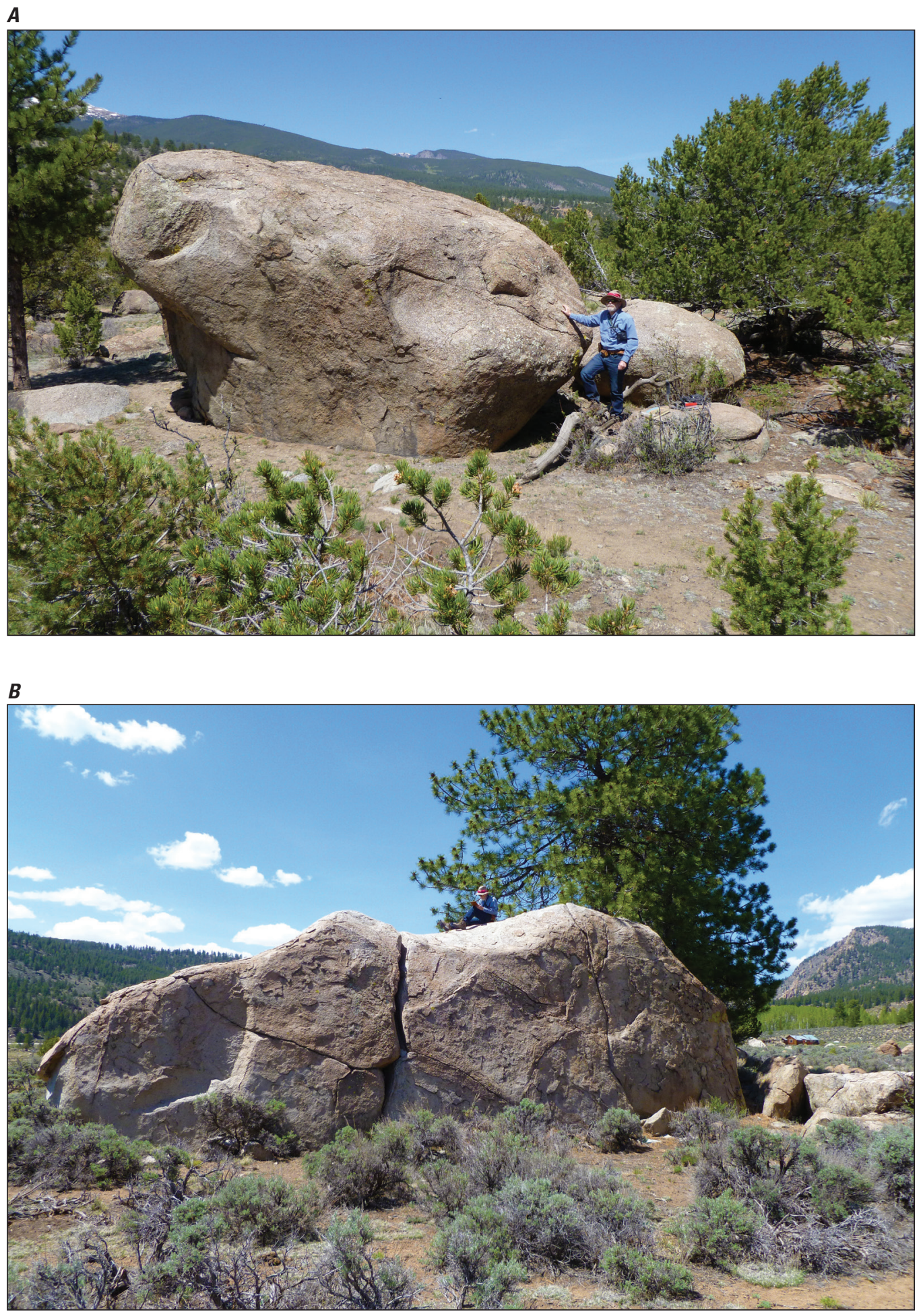

Figure 1. A, Enormous granitic flood boulder on Qpo terrace. Boulder measures about $8 \mathrm{~m} \times 6 \mathrm{~m} \times 4+\mathrm{m}$. View is to the north. $B$, The largest flood boulder known in the Arkansas Valley, on Qpoo terrace at location $2 B$ on map sheet. Boulder measures $14 \mathrm{~m} \times 5 \mathrm{~m} \times 5+\mathrm{m}$. View is to the north. Note person on boulder for scale. 


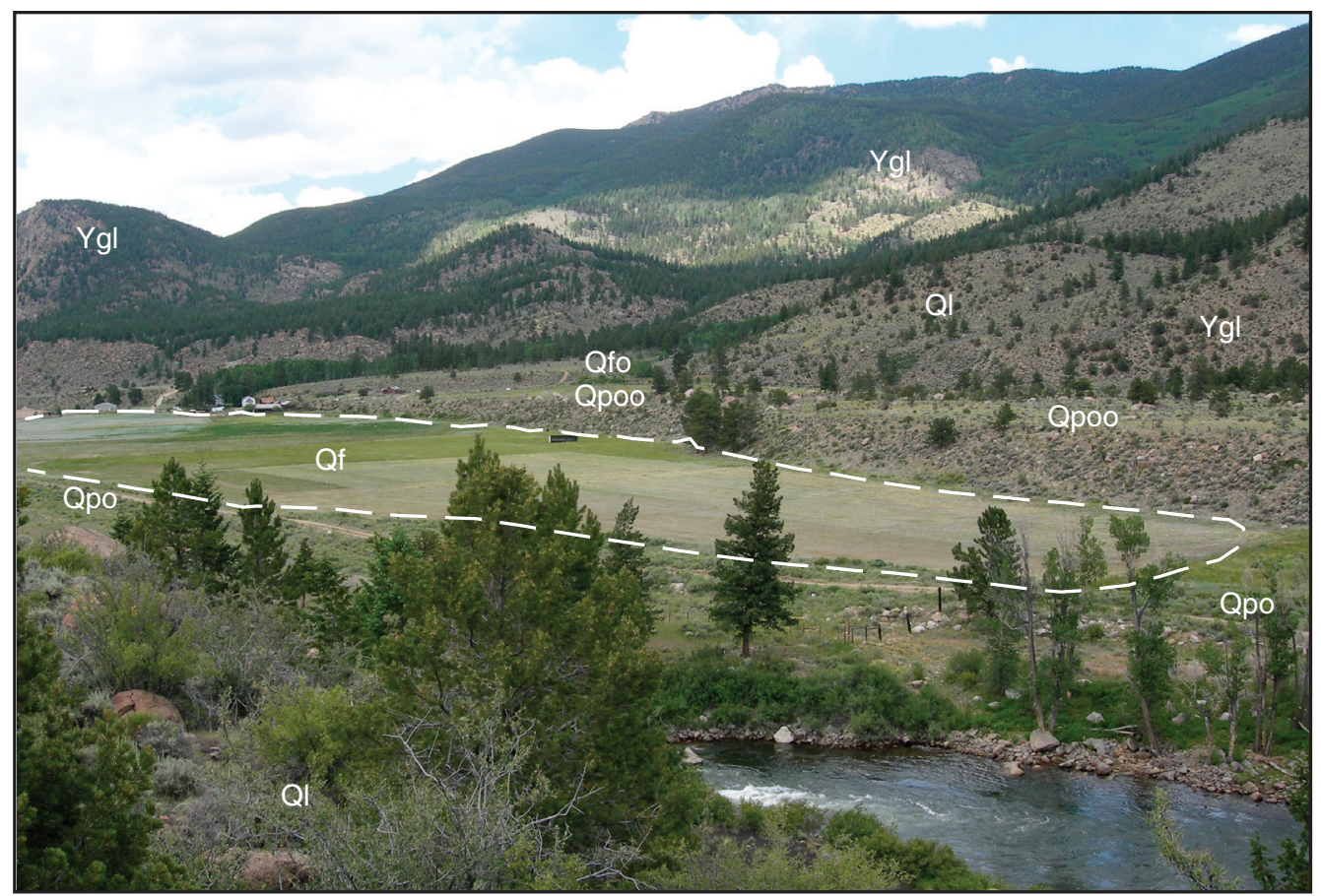

Figure 2. View to northeast from Highway 24 of terraces along Arkansas River. Lower terrace, here covered by alluvial fan deposits (Qf), is underlain by younger Pinedale-age outwash deposit (Qpo) on which a fan deposit (Qf) emanating from Tumble Creek has formed. Higher terrace is underlain by older Pinedale-age outwash deposit (Qpoo), with visible large outwash boulders, some longer than $5 \mathrm{~m}$. The Qpoo terrace cuts into the front of the old fan deposit (Qfo), whose age must be early Pinedale or older. A landslide deposit (QI) underlies the hill on the right and the near boulder deposits on the left. Most of the mountainous area in the image is underlain by granite of Langhoff Gulch (Ygl).

Piedmont-slope deposit of Bull Lake glaciation (late and middle? Pleistocene) - Grayish-brown, sandy, bouldery alluvium containing subrounded boulders as long as $1 \mathrm{~m}$, although most are considerably smaller. Forms bajadas west of Arkansas River created by coalescing alluvial fans and channel deposits emanating from Sawatch Range. Source primarily from till of Bull Lake glaciation. Estimated thickness about $10 \mathrm{~m}$

Old piedmont-slope deposit (middle Pleistocene) - Grayish-brown to reddish-brown, moderately stratified alluvium consisting of gravel with clasts as large as about $2 \mathrm{~m}$ long in a silty-sand matrix; most clasts less than $0.5 \mathrm{~m}$ in diameter. Well-developed soil. Forms bajadas west of Arkansas River created by coalescing alluvial fans and channel deposits emanating from Sawatch Range; overlies older alluvial deposits or Tertiary Dry Union Formation. Clasts consist of Proterozoic igneous and metamorphic rocks and Tertiary intrusive rocks. Called "Kansan(?) alluvium" by Scott (1975), who correlated deposit with "Pearlette ash" (639 \pm 2 ka Lava Creek B tuff; Lanphere and others, 2002) from eruption in Yellowstone National Park

Old alluvial gravel of Arkansas River (middle Pleistocene) - Light-brown to grayish-brown, poorly stratified, coarse to very coarse gravel that contains large, mostly granitic boulders, indicating at least part of unit deposited during large middle Pleistocene flood (Lee, 2010). Flood boulders are concentrated near base of unit, are generally stacked upon each other, and are commonly widely dispersed in the gravel. Flood boulders as long as $4 \mathrm{~m}$ are common, and boulders longer than $6 \mathrm{~m}$ are not rare. The largest flood boulder observed in these deposits is a gneissic granodiorite $8.1 \mathrm{~m} \times 5.0 \mathrm{~m} \times 2.7+\mathrm{m}$. Deposit also includes well-rounded gravel in a sandy matrix that increases in relative amount and becomes finer grained upward and includes abundant porphyry and Paleozoic quartzite clasts; well-rounded clasts are as long as about $0.7 \mathrm{~m}$. This indicates flood deposition was followed by a through-going river with a sediment source near Leadville, about $25 \mathrm{~km}$ north of the map area. Near the mouth of Morris Creek, unit forms discontinuous remnants of a middle Pleistocene strath terrace overlying Dry Union Formation. On both sides of the valley, gravel deposits are as thick as about $9 \mathrm{~m}$ and are about $58 \mathrm{~m}$ above river level. Correlated with "Kansan(?) alluvium" of Scott (1975) and McCalpin and Shannon (2005), so is approximately coeval with old piedmont-slope deposit (Qg3) on west side of river, with which it either overlies or is interbedded 
Qg2

Qn

Qf

Qac

Qfo

Qc

Qt

QI

Very old piedmont-slope deposit (middle to early Pleistocene) - Light-brown to gray, poorly sorted, poorly stratified, deeply weathered sandy, boulder gravel derived from Sawatch Range to the west. Contains boulders as long as about $2 \mathrm{~m}$. Soil very deeply weathered. Underlies east-sloping surface in south part of quadrangle. Called "Nebraskan(?) alluvium" by Scott (1975) and McCalpin and Shannon (2005). Thickness estimated as much as $24 \mathrm{~m}$

Nussbaum(?) alluvium of Scott (1975) (early Pleistocene) - Grayish-brown, poorly stratified, boulder alluvium containing moderately rounded to well-rounded boulders as large as about $1 \mathrm{~m}$ long in orange-gray, clayey matrix; very strongly developed soil. Contains large percentage of dark-brown subangular to subrounded andesite porphyry clasts from Buffalo Peaks and well-rounded Paleozoic quartzite. Three deposits about $90 \mathrm{~m}$ above Arkansas River in southeastern part of quadrangle east of Arkansas River. ated thickness as much as about $10 \mathrm{~m}$. Called "Nussbaum(?) alluvium" by Scott (1975)

\section{Alluvial and Mass-Movement Deposits}

Fan deposit (Holocene to middle Pleistocene)—Pale yellowish-brown to grayish-brown, poorly to moderately well sorted, crudely stratified, sand and gravel in fan-shaped deposits of smaller tributaries of major streams. Deposits are both clast and matrix supported, suggesting deposition by both alluvial and debris-flow processes. Clasts mostly subangular to subrounded; some are as long as about $2 \mathrm{~m}$, but most are considerably smaller. In most places, unit grades to present stream level. Most are still actively forming, but probably most active during Pinedale glaciation. Includes large gravel apron near and mostly between Powell Creek and Three Elk Creek in southwestern part of quadrangle that grades to middle Pleistocene piedmont-slope deposit (Qg3) and displays well-developed braided pattern

Alluvium and colluvium, undivided (Holocene to middle? Pleistocene) -Alluvium composed of typically poorly sorted silt to boulder gravel in narrow channels that are too small to map separately. Alluvium is flanked by colluvial deposits composed of mostly poorly sorted, angular clasts as long as $1 \mathrm{~m}$ in a matrix of clay, silt, and sand derived from weathered bedrock and transported downslope. Colluvium is locally mantled by thin loess. Typically less than $10 \mathrm{~m}$ thick

Old fan deposit (late to middle? Pleistocene) - Mostly grayish-brown to light brown, poorly sorted sand and gravel deposited in an alluvial apron that grade to middle Pleistocene piedmont-slope deposit (Qg3). Clasts subrounded to subangular and generally as long as $2 \mathrm{~m}$, although a few clasts may be larger. Moderately dissected. Large Qfo deposit west of Arkansas River displays well-developed braided channels, grades to Qg3 piedmont-slope gravel and is derived mainly from erosion of till of Bull Lake glaciations, but may include some deposits of pre-Bull Lake age. An old fan deposit at the mouth of Tumble Creek is shown in figure 2

\section{Mass-Movement Deposits}

Colluvium (Holocene to middle? Pleistocene) - Unconsolidated to weakly consolidated, mostly non-stratified, non-sorted, dark brown to light-gray-brown deposits that mantle surfaces that slope less than about 50 degrees. Clasts and fine-grained material accumulated by downslope movement. Contains angular pebbles, cobbles, and boulders with compositions that reflect upslope bedrock and surficial deposits. Includes material transported by creep, unconfined overland flow, landslide, debris flow, hyperconcentrated flow, and rock fall. Locally includes minor deposits of stream-channel and sheetwash alluvium, as well as periglacial deposits, formed chiefly by frost wedging and solifluction (above treeline, about 3,500 m elevation) on Buffalo Peaks. Locally overlain by loess deposits as much as about $50 \mathrm{~cm}$ thick, composed of very fine sand, silt, and minor clay. Commonly underlies areas of open meadows, sagebrush, or aspen groves. Maximum thickness probably less than $10 \mathrm{~m}$

Talus deposit (Holocene to middle Pleistocene) - Angular and subangular cobble- and boulder-sized fragments that form angle-of-repose deposits below steep rocky outcrops or cliffs. Sandy matrix rarely is exposed. Boulders generally are as large as $2 \mathrm{~m}$, but locally may be as large as $10 \mathrm{~m}$. Mapped deposits in quadrangle are below Buffalo Peaks where clasts are predominantly volcanic

Landslide deposit (Holocene to middle? Pleistocene) - Deposits are mostly earth slides and earth flows (terminology of Cruden and Varnes, 1996), characterized by hummocky topography, well formed, relatively steep, crescent-shaped, mostly unvegetated headwall scarps, and downslope lobate toes. Large landslide deposit in northwest part of map area (Pine Creek School landslide) formed largely from remobilization of Bull Lake-age till, but also included some Pinedale-age till. The Pine Creek School landslide moved during at least three stages; scarps on map separate stages, from oldest to youngest from west to east. Deposits of the youngest, eastern landslide have very hummocky topography, numerous closed depressions, some of which contain small lakes, and relatively fresh scarps, all of which suggest at least some Holocene movement. 
Lower part of landslide overlain by patches of flood boulders that may have preceded at least some sliding. Large deposit in central part of sec. 29, T.12 S., R.78 W. consists of angular blocks of andesite of Buffalo Peaks ( $\mathrm{E}$ ba). Large landslide deposits are also mapped just east of Fourmile Creek near eastern border of quadrangle. Numerous other smaller landslide deposits mapped in many places

Debris-flow deposit (Holocene to middle? Pleistocene) - Unsorted and unstratified bouldery deposit containing clay- to boulder-size clasts; both clast supported and matrix supported deposits occur. Topography smooth to hummocky. Largest deposit southwest of Buffalo Peaks on Fourmile Creek composed predominantly of Buffalo Peaks volcanic rocks and granite of Langhoff Gulch, where deposit consists of probable till of Pinedale age (Qtp), colluvium (Qc), and landslide deposits (Ql)

\section{Mass-Movement and (or) Glacial Deposits}

Periglacial deposit (Holocene to early? Pleistocene) - Deposits of angular blocks as long as about $3 \mathrm{~m}$ composed mostly of Mesoproterozoic granite of Langhoff Gulch, just west of Buffalo Peaks. Typically form by periglacial processes (chiefly solifluction and freeze-thaw wedging) in non-glaciated, alpine areas above about 3,600 m during glacial and periglacial episodes. At surface, blocks commonly have open spaces between them or contain a dark-brown gravelly soil that is a combination of material derived from mechanical weathering of blocks and smaller rock fragments and deposition of eolian silt (loess). Composition of blocks same as immediately underlying bedrock. Thickness is probably less than $5 \mathrm{~m}$

Diamicton (late to early Pleistocene) - Unsorted, unstratified bouldery deposit in upper Fourmile Creek valley composed of clasts from Buffalo Peak volcanics and Proterozoic rocks. Soil weathered and clasts mostly buried, indicating older than Pinedale glaciation. Origin uncertain; represents till of Bull Lake or pre-Bull Lake glaciation, or debris flow deposit. Mapped at one locality in upper Fourmile Creek

\section{Glacial Deposits}

Till of Pinedale glaciation, undivided (late Pleistocene) - Mostly non-sorted and non-stratified, matrix-supported deposits left from melting of glaciers of Pinedale glaciation. Matrix (clasts less than $2 \mathrm{~mm}$ in diameter) is estimated to comprise 20-40 percent of deposit and consists chiefly of poorly sorted sand and a minor amount of silt and clay. Most of the biotite-rich granitic and gneissic clasts within soil are unweathered; disintegrated clasts are rare. Unit locally includes minor deposits of stratified drift, colluvium (Qc) and other mass-movement deposits, and minor alluvium $(\mathrm{Qa})$. Unit commonly forms large, very bouldery, sharp-crested lateral and end moraines that have distinct hummocky morphology. Soil has a thin B horizon that is poorly developed with little or no clay accumulation. Forms prominent moraines in valleys of Pine Creek, Frenchman Creek, and Three Elk Creek. ${ }^{10} \mathrm{Be}$ cosmogenic exposure dating of moraine crests in Pine Creek indicate two periods of glacial maxima: $22.0 \pm 1.4 \mathrm{ka}$ and $15.2 \pm 0.9 \mathrm{ka}$ (Briner, 2009). These ages are in general agreement with radiogenic and cosmogenic-exposure ages on till of Pinedale age from: (1) Front Range region of about 12-30 ka (Nelson and others, 1979; Madole, 1986; Benson and others, 2004, 2005), (2) retreat of Pinedale glaciers in the San Juan Mountains, Colorado, between 19 and $12 \mathrm{ka}$ (cosmogenic ages of Guido and others, 2007), (3) last glacial maximum in the Taylor River drainage, about $25 \mathrm{~km}$ west of the quadrangle, of about $20 \mathrm{ka}$, and a "late stagnation age" of about $14.5 \mathrm{ka}$ (cosmogenic ages of Brugger, 2007), (4) ages of 16-23 ka from Pinedale deposits in type area in Wyoming (Chadwick and others, 1997), and (5) 13.5-18.8 ka from greater Yellowstone area and Teton Range (Licciardi and Pierce, 2008). Estimated thickness is as much as $30 \mathrm{~m}$

Younger till of Pinedale glaciation (late Pleistocene) - Forms major portion of Pinedale-age till in Pine Creek. Deposited on and partially displaces older till of Pinedale glaciation (Qtpo), so represents resurgent pulse of glaciation

Older till of Pinedale glaciation (late Pleistocene) - Forms outlying portion of Pinedale-age till on eastern side of Pine Creek drainage; overlapped by younger till of Pinedale glaciation (Qtpy)

Till of Bull Lake glaciation, undivided (late and middle Pleistocene) - Mostly non-sorted and non-stratified subangular to subrounded boulders as long as $4 \mathrm{~m}$ to granules in a silty sand matrix; clasts are matrix supported. Matrix (clasts less than $2 \mathrm{~mm}$ in diameter) is estimated to comprise 20-40 percent of deposit. Unit forms prominent lateral moraines with rounded crests beyond, and extending laterally outward from, lower limit of till of Pinedale age (Qtp), as in valleys of Pine Creek, Frenchman Creek, Three Elk Creek, and Powell Creek. Surface boulders typically are less abundant on moraines of Bull Lake glaciation than on those of Pinedale glaciation. Bull Lake till (Qtb) is more weathered and its surface morphology is smoother and less hummocky than Pinedale till (Qtp). Boulders of Proterozoic gneiss and plutonic rock commonly have weathered rinds. Locally includes minor deposits of stratified drift. Soil formed in till of Bull Lake age 
has an orange-brown B horizon, typically $20-50 \mathrm{~cm}$ thick, of clay and iron-oxide accumulation. The B horizon overlies unweathered or slightly weathered till. Small areas of alluvium and colluvium locally overlie unit. Two ages of Bull Lake till mapped in valley of Pine Creek, based on relative positions (Scott, 1975). Age of Bull Lake glaciation in type area in Wind River Range of Wyoming is $95 \mathrm{ka}$ to $>130 \mathrm{ka}$ (Chadwick and others, 1997). More recent $\mathrm{K}-\mathrm{Ar}$ and ${ }^{230} \mathrm{Th} / \mathrm{U}$ dating near type area, and ${ }^{10} \mathrm{Be}$ and helium-3 $\left({ }^{3} \mathrm{He}\right)$ ages of glacial deposits near West Yellowstone and the Teton Range, indicate that Bull Lake glaciation probably began prior to $167 \pm 6.4 \mathrm{ka}$ and may have continued until about $120 \mathrm{ka}$ (Sharp and others, 2003; Pierce, 2004; Licciardi and Pierce, 2008). These studies are in general agreement with: (1) dramatic decreases in worldwide temperatures between about $190 \mathrm{ka}$ and $135 \mathrm{ka}$ as recorded in benthic ${ }^{18} \mathrm{O} /{ }^{16} \mathrm{O}$ ratios (Lisiecki and Raymo, 2009), (2) ${ }^{10} \mathrm{Be}$ and ${ }^{26} \mathrm{Al}$ analyses of surface boulders on Bull Lake moraines near Nederland, Colorado, about $110 \mathrm{~km}$ northeast of map area, that yielded minimum age estimates of $101 \pm 21 \mathrm{ka}$ and $122 \pm 26 \mathrm{ka}$ (Schildgen and others, 2002), and (3) a uranium-trend age estimate of $130 \pm 40$ ka for Bull Lake till (Shroba and others, 1983) near Allens Park, Colorado, about $140 \mathrm{~km}$ northeast of map area. Thickness may locally exceed $30 \mathrm{~m}$.

Younger till of Bull Lake glaciation (late and middle(?) Pleistocene) - Mapped adjacent to Pine Creek. Deposited on and partially displaces older till of Bull Lake glaciation (Qtbo), so represents resurgent pulse of glaciation

\section{Qtbo}

Qtpb

Older till of Bull Lake glaciation (late or middle Pleistocene) - Mapped adjacent to Pine Creek. Partially displaced by and underlies younger till of Bull Lake glaciation

Till of pre-Bull Lake glaciation (middle or early Pleistocene) - Brownish-orange, deeply weathered, unstratified, unsorted bouldery deposit containing clasts larger than $3 \mathrm{~m}$. Lacks morainal morphology. Mapped at two localities at Frenchman Creek. Estimated thickness greater than $40 \mathrm{~m}$

\section{Lacustrine Deposits}

Pond alluvium (Holocene and late Pleistocene) - Sand and gravel deposited in closed depressions in large landslide deposit (Ql) just west of State Highway 24 in NW1/4, sec. 27, and near center of sec. 34, R. 79 W., T. $12 \mathrm{~S}$.; rarely filled by water

Lacustrine deposit (late Pleistocene) - Light greenish-gray, poorly indurated, very fine grained laminated, silty sand, with laminations folded by slumping; deposited in moraine-dammed lake along northern border of quadrangle; exposed mostly in 20-m-wide outcrop in Pine Creek drainage, overlain by bouldery alluvial gravel derived from till of Pinedale glaciation (Qtp)

\section{Volcanic Ash Deposit}

Lava Creek B ash and fluvial sediments (middle Pleistocene) - Very pale tan (almost white), poorly consolidated, weakly stratified, fine-grained, air-fall ash bed (locally water worked) as thick as about $50 \mathrm{~cm}$, locally interbedded with reddish-orange, laminated, weakly indurated arkosic sand containing small hematitic concretions. Ash contains abundant glass shards less than $0.5 \mathrm{~mm}$ long. Unit Qaa overlies boulder gravel of unit Qao. Two outcrops in quadrangle: in NE $1 / 4$, sec. 13, T. 13 S., R. 79 W., small outcrop in gully has a buttress unconformity with underlying granite of Langhoff Gulch (Ygl) (fig. 3); small outcrop also in gully in $\mathrm{SW}^{1} 1 / 4$, sec. 18, T. 13 S., R. 78 W. Age of Lava Creek B ash is 639 \pm 2 ka (Lanphere and others, 2002)

\section{Basin-fill Deposit}

Dry Union Formation (Pliocene and Miocene) - Mostly light-brown or orange-brown, but locally gray, reddishgray, or greenish-gray, consolidated to semi-consolidated, weakly to well stratified, locally cross-stratified clay, silt, silty sand, and gravel. Clasts composed of Proterozoic gneiss and igneous rocks and Tertiary volcanic rocks, generally less than $10 \mathrm{~cm}$ in diameter, but locally larger. Locally contains ashy sandstone beds. Mostly overlain by Quaternary deposits, but exposed in several places along river-eroded bluffs and near mouths of creeks on west side of river. Dips very gently west due to general down dropping of west side of valley along faults. Thickness in Arkansas River valley probably more than 1,600 $\mathrm{m}$ in places (Tweto, 1979), although thickness in quadrangle is considerably less than this amount

\section{Volcanic Rocks of Buffalo Peaks (Upper Eocene)}

Cap andesite - Dark greenish-gray andesite porphyry flow capping West Buffalo Peak. Aphanitic matrix comprises about 60 percent of rock; also contains about 25 percent euhedral, strongly sausseritized plagioclase as long as $3 \mathrm{~mm}, 9$ percent euhedral to subhedral augite, 4 percent opaque minerals, 2 percent strongly altered (to opaque minerals) hornblende, 1 percent hypersthene, and trace sphene. Locally contains light-gray fine-grained angular lithic fragments as long as $1 \mathrm{~cm}$. Rock strongly jointed, with light-green, fine-grained material (probably epidote and chlorite) in partings parallel to joints 


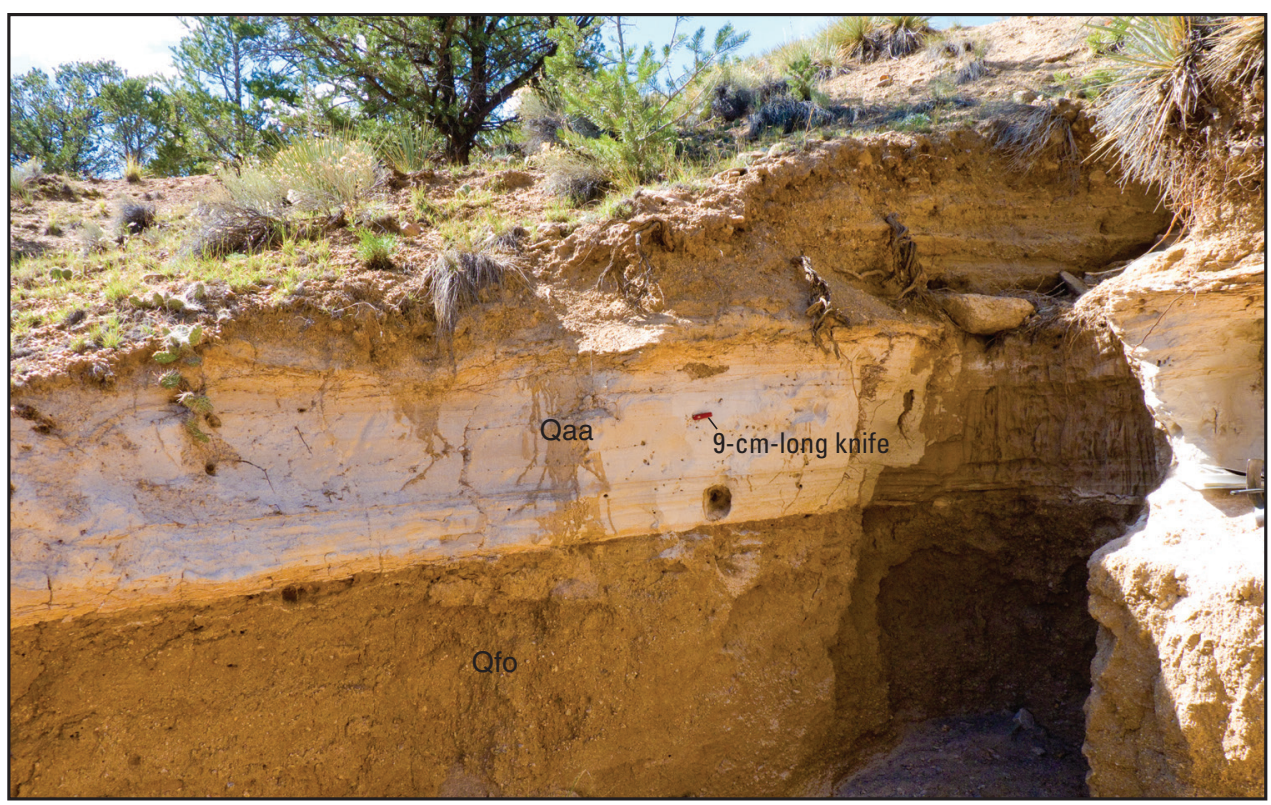

Figure 3. View to north of 50-cm-thick air-fall ash interpreted to be Lava Creek B ash (Qaa), erupted from the Yellowstone region $639 \pm 2 \mathrm{ka}$ (Lanphere and others, 2002). Ash overlies old gravel deposit of Arkansas River (Qao; not visible in this image) and is interbedded with old fan deposit (Qfo). Note 9-cm-long knife for scale.

Pebb

Pebt

Pebal

PEbn

PEai

PEKdc

Basal andesite flow breccia-Reddish-brown andesite porphyry flow breccia. Forms basal unit of capping andesite of Buffalo Peaks (PEba), so composition similar to that unit

Tuff of Buffalo Peaks - Reddish-brown and black, flow-foliated andesitic ash-flow tuff about $60 \mathrm{~m}$ below basal andesite flow breccia. Contains well-developed fiamme and small, rounded pumice fragments as long as $1 \mathrm{~cm}$. In thin section, about 75 percent of rock is glass; remainder is about 6 percent plagioclase, 4 percent opaque minerals, 4 percent partially resorbed hornblende, 3 percent brown biotite, 3 percent augite, and 3 percent clear, fragmental quartz. Formerly correlated with the Badger Creek Tuff (Scott, 1975; Sanders, 1975), which erupted from the Mount Aetna caldera, but new ${ }^{40} \mathrm{Ar} /{ }^{39} \mathrm{Ar}$ date of $37.9 \pm 0.3 \mathrm{Ma}$ (sample HL09-170, location D; table 1), in agreement with date of 38.18 \pm 0.32 (McIntosh and Chapin, 2004) is considerable older than ${ }^{40} \mathrm{Ar} r{ }^{39} \mathrm{Ar}$ date of 33.81 \pm Ma for the Badger Creek Tuff (McIntosh and Chapin, 2004). Source of tuff of Buffalo Peaks unknown

Lower andesite flow - White, strongly altered ("bleached") andesite with assumed composition similar to cap andesite (PEba) exposed over several meters just above granite of Elephant Rock (Yge). Prominent platy jointing (strike/dip is 315/30) probably reflects regional dip

\section{Hypabyssal Rocks}

Basaltic andesite (late Eocene) - Black, aphanitic, massive porphyritic rock containing about 5 percent hornblende crystals as long as $3 \mathrm{~mm}$, about 2 percent plagioclase crystals as long as about $2 \mathrm{~mm}$, and about 1 percent olivine crystals as long as $1 \mathrm{~mm}$. Crops out over small area just west of intrusive andesite (Ptai) in northeast corner of quadrangle. Interpreted as intrusive

Intrusive andesite (late Eocene) - Dark greenish-gray, fine-grained, equigranular rock containing mostly sericitic plagioclase, hornblende, and opaque minerals. Similar in composition to cap andesite (Paba) of Buffalo Peaks and may be feeder for Buffalo Peaks volcanic rocks. Well layered parallel to fracture cleavage. Interpreted as intrusive. Exposed over 0.5 -km-wide area about $1.5 \mathrm{~km}$ south of main volcanic rocks of Buffalo Peaks

Rhyodacite and dacite dike (middle Eocene to Late Cretaceous?) - Medium- to light-gray porphyritic dikes containing prominent white phenocrysts of plagioclase and black biotite. Dull luster on fractures. Includes rhyodacite and dacite dikes mapped by Scott (1975) and those mapped for this study. Prominent sheared and mineralized dike in secs. 4 and 5, T. 13 S., R. 79 W. intruded a fault zone during faulting and consists of finegrained, equigranular, granoblastic mosaic of plagioclase, quartz and about 10 percent biotite, 2 percent opaque minerals, and traces of muscovite and garnet; tailings at mine workings along dike in Morrison Creek show considerable copper staining. Little Anne Mine and several prospects in sec. 6, T. 13 S., R. 78 W. are also in and 
Table 1. New isotopic dates determined for Harvard Lakes quadrangle.

[bt, biotite; hb, hornblende; zr, zircon]

\begin{tabular}{|c|c|c|c|c|c|c|c|c|}
\hline $\begin{array}{l}\text { Letter } \\
\text { on map }\end{array}$ & $\begin{array}{l}\text { Sample } \\
\text { number }\end{array}$ & Rock name & Map unit & \multicolumn{2}{|c|}{ Location } & $\begin{array}{c}\text { Mineral } \\
\text { analyzed }\end{array}$ & Technique* & Age \\
\hline B & HL09-44 & hb monzonite dike & $\mathrm{PEKm}$ & 393692 & 4311539 & bt & ${ }^{40} \mathrm{Ar} /{ }^{39} \mathrm{Ar}$ & $68.1 \pm 0.5 \mathrm{Ma}$ \\
\hline $\mathrm{D}$ & HL09-170 & lower tuff of Buffalo Peaks & Pebt & 402229 & 4316142 & $\mathrm{hb}$ & ${ }^{40} \mathrm{Ar} /{ }^{39} \mathrm{Ar}$ & $37.9 \pm 0.3 \mathrm{Ma}$ \\
\hline E & HL09-53 & granite of Langhof Gulch & Ygl & 394929 & 4315994 & $\mathrm{zr}$ & ${ }^{207} \mathrm{~Pb} /{ }^{206} \mathrm{~Pb}$ & $1,446 \pm 50 \mathrm{Ma}$ \\
\hline $\mathrm{F}$ & HL09-121 & granite of Elephant Rock & Yge & 400600 & 4305320 & $\mathrm{zr}$ & ${ }^{207} \mathrm{~Pb} /{ }^{206} \mathrm{~Pb}$ & $1,438 \pm 7 \mathrm{Ma}$ \\
\hline
\end{tabular}

${ }^{* 40} \mathrm{Ar} /{ }^{39} \mathrm{Ar}$ analysis carried out at U.S. Geological Survey, Denver, Colo.; ${ }^{207} \mathrm{~Pb} /{ }^{206} \mathrm{~Pb}$ analysis carried out at joint U.S. Geological Survey-Stanford SHRIMP facility at Menlo Park, Calif.

along a pale-gray, very-fine-grained, sugary, equigranular dacite dike containing abundant fine-grained biotite flakes. Large, 25-m-wide dike in sec. 20, T. $13 \mathrm{~S}$., R. $78 \mathrm{~W}$. is a very altered, pale-yellow, fine-grained, massive, leucocratic dacite containing phenocrysts of white plagioclase and sparse biotite as long as $5 \mathrm{~mm}$. Dikes mostly less than $10 \mathrm{~m}$ wide. Similar dacitic to rhyolitic dikes in the Buena Vista East quadrangle, southeast of the map area, are overlain by the $37.49 \pm 0.22$ Ma upper tuff of Triad Ridge (Keller and others, 2004; McIntosh and Chapin, 2004), so the dikes are middle Eocene or older. Unit most likely intruded during early Paleocene to Late Cretaceous period of silicic magmatism in region

PEKm Hornblende monzonite (early Paleocene or Late Cretaceous) - Forms a 0.8-km-long stock, oval in outcrop, just south of Morrison Creek (in N1/2, sec. 4, T. 13 S., R. 79 W.), and a 20-m-wide, east-striking dike about $200 \mathrm{~m}$ south of stock. The oval stock is gray, medium-grained, equigranular, massive monzonite containing, in one typical thin section, about 53 percent plagioclase, 34 percent microcline, 7 percent hornblende, 2 percent clinopyroxene, 2 percent large (to $2 \mathrm{~mm}$ ) sphene, 1 percent biotite, 1 percent hypersthene, and 1 percent opaque minerals. Contains no visible quartz. Dike is dark gray, fine grained, equigranular, massive, and contains about 50-60 percent very sericitized plagioclase and microcline, 25 percent biotite, 10 percent hornblende, and 5 percent opaque minerals. Contains no visible quartz. ${ }^{40} \mathrm{Ar}{ }^{39} \mathrm{Ar}$ biotite age for the stock is $65.4 \pm 0.5 \mathrm{Ma}$ (sample HL09-89; location A; table 1); ${ }^{40} \mathrm{Ar} /{ }^{39} \mathrm{Ar}$ biotite age for the dike is $65.3 \pm 0.5 \mathrm{Ma}$ (sample HL09-44; location B; table 1)

PEKrq Quartz rhyolite porphyry dike (early Paleocene or Late Cretaceous) - White, finely crystalline dikes as wide as about $10 \mathrm{~m}$ containing phenocrysts of bipyramidal quartz as long as about $5 \mathrm{~mm}$, feldspar, and biotite. Fracture chonchoidal and glassy. Includes dikes mapped by Scott (1975) and those mapped for this study. Whole-rock K-Ar age for similar rhyolite dike in South Peak quadrangle immediately to north is 65.3 $\pm 2.4 \mathrm{Ma}$ (Marvin and others, 1989)

$\mathrm{PEKr} \quad$ Rhyolite and quartz latite dikes of Scott (1975) (early Paleocene or Late Cretaceous) — Medium- to lightgray, glassy to finely crystalline, generally nonporphyritic dikes. Some have well-oriented planar concentrations of fine-grained biotite. Undated, but likely intruded during early Paleocene to Late Cretaceous period of intrusive activity in region

Khbg Hornblende-biotite gabbro or diorite (Late Cretaceous) - Gray, massive hornblende porphyry; matrix fine- to medium-grained; contains phenocrysts of hornblende as long as $1 \mathrm{~cm}$. One thin section contains 55 percent zoned subhedral to euhedral plagioclase as long as $1.5 \mathrm{~mm}, 17$ percent euhedral hornblende containing abundant secondary biotite, 19 percent both primary and secondary biotite, 6 percent equant opaque mineral (magnetite?), 2 percent clear to slightly undulatory quartz, and trace apatite and sphene. Forms $0.7 \mathrm{~km}-\mathrm{long}$, crescent-shaped plug along Buffalo Creek east of Arkansas River, and two smaller plugs several hundred meters south of larger plug. ${ }^{40} \mathrm{Ar} /{ }^{39} \mathrm{Ar}$ age on biotite is $68.1 \pm 0.9 \mathrm{Ma}$ (sample HL09-136; location C; table 1). Unit also includes a small plug in the SE 1/4, sec. 6 T. 13 N., R. 78 W. consists dark greenish-gray, massive, very fine grained, nonporphyritic hornblende-plagioclase-chlorite (after biotite) rock; contains abundant black hornblende needles as long as $1 \mathrm{~mm}$

\section{Paleozoic Sedimentary Rocks}

OEm Manitou Formation (Lower Ordovician and Upper Cambrian) — Light to dark-gray, thin- to thick-bedded, fine to medium-grained dolomite commonly containing white chert lenses and stringers. Weathers to light yellowish gray or brown. Only about lower $10 \mathrm{~m}$ of formation are poorly exposed in northeastern corner of quadrangle. Includes Upper Cambrian Taylor Pass Member of Manitou of Myrow and others (2003) 
$€ d s \quad$ Dotsero Formation and Sawatch Quartzite, undivided (Upper Cambrian) - Sawatch Quartzite consists of white, light-brown to pale pinkish-brown, hard, medium-grained quartz sandstone, locally containing vertical worm burrows. Grades upsection into mottled orange and dark-purplish-brown, poorly sorted, wavylaminated, silty quartz sandstone, typical of Dotsero Formation. Sawatch Quartzite in Jones Hill quadrangle immediately to the northeast about $55 \mathrm{~m}$ thick, and Dotsero Formation about $15 \mathrm{~m}$ thick (Widmann and others, 2011). Combined unit about $20 \mathrm{~m}$ thick in quadrangle; top of combined unit poorly exposed

\section{Proterozoic Igneous and Metasedimentary Rocks}

Yqd Quartz diorite (Mesoproterozoic) - Dark- to medium-gray, medium- to coarse-grained, equigranular to weakly porphyritic rock composed of plagioclase (oligoclase-andesine), hornblende, biotite, and minor quartz and microcline. Generally has a "salt-and-pepper" appearance. Immediately to the south in the Buena Vista East quadrangle, contact relationship with granite of Elephant Rock is "ambiguous" and the two units may be comagmatic (Keller and others, 2004). Occurs as three small stocks intruding monzogranite of Langhoff Gulch $(\mathrm{Ygl})$ and monzogranite of Elephant Rock (Yge) in southeastern part of quadrangle

Yhy Intermixed granite of Langhoff Gulch and granite of Elephant Rock (Mesoproterozoic) _Zones of intimately intermixed granite of Langhoff gulch and granite of Elephant Rock. Granite of Langhoff Gulch intrudes or partially assimilates granite of Elephant Rock, indicating that it is slightly younger. Contacts are both gradational and sharp, indicating similarity in age

Ygl Granite of Langhoff Gulch (Mesoproterozoic) - Gray, medium-grained, equigranular to inequigranular, massive to weakly flow-foliated, syenogranite, monzogranite, and granodiorite. Contains about 25-35 percent quartz, 20-40 percent plagioclase, $12-45$ percent microcline, 4-20 percent biotite, 1-2 percent muscovite, trace to 1 percent sphene, and traces of zircon and apatite; locally contains sparse rutile and garnet. Dikes and bodies of granite of Langhoff Gulch intrude granite of Elephant Rock in many places (fig. $4 A$ ) and contain inclusions of granite of Elephant Rock (fig. 4B). New U-Pb zircon age from location E (sample (HL09-53, table 1) is $1,446 \pm 50 \mathrm{Ma}$ (table 1), although an age from the same pluton in the adjacent Marmot Peak quadrangle is $1,443 \pm 40$ Ma (W.R. Premo, USGS, written commun., 2012). In most locations unit weathers to distinctive reddish-brown to light grayish-brown, rounded to blocky outcrops

Yge Granite of Elephant Rock (Mesoproterozoic) - Gray to grayish-pink, coarse-grained, massive to moderately foliated, porphyritic monzogranite. Contains 30-35 percent quartz, 25-30 percent plagioclase (oligoclase), 30-32 percent microcline, 6-12 percent biotite, 1-2 percent sphene, and traces of apatite, zircon, and opaque minerals. Microcline phenocrysts are as long as $3 \mathrm{~cm}$. Same unit in adjacent Buena Vista West quadrangle (McCalpin and Shannon, 2005) immediately south of Harvard Lakes quadrangle, called "granodiorite," correlated with "similar" granodiorite in the Cameron Mountain quadrangle to southeast, with reported age of 1,672 $\pm 5 \mathrm{Ma}$ (Bickford and others, 1989). However, new U-Pb zircon age from location F (sample HL09-121, table 1) is 1,438 $7 \mathrm{Ma}$ (table 1), so unit is Mesoproterozoic in age. The reasons for this discrepancy in ages have not yet been resolved. Commonly weathers into distinctive rounded, reddish torrs with intervening reddish grus

Ygef Augen gneiss facies of granite of Elephant Rock - Gray, well-foliated equigranular to porphyritic, biotiteplagioclase-microcline-biotite gneiss (fig. 5). Augen gneiss in most places, with microcline augens as long as $3 \mathrm{~cm}$. Represents highly strained facies of granite of Elephant Rock. Interlayered in some places with biotite gneiss

YXhm Hornblende monzodiorite (Meso- or Paleoproterozoic) - Dark-gray, medium-grained, equigranular to porphyritic, massive to weakly foliated, with plagioclase phenocrysts as long as $1 \mathrm{~cm}$; ranges from monzodiorite to quartz monzodiorite. Mineral content is about 3-6 percent quartz, 30 percent plagioclase, 20 percent microcline, 20-40 percent hornblende, 5 percent biotite, 1-3 percent sphene, 1 percent opaque minerals, and trace apatite zircons and opaque minerals. Forms one body between monzogranite of Elephant Rock and monzogranite of Langhoff Gulch in and near headwaters of Rock Creek, east of Arkansas River

Xgd Foliated granodiorite (Paleoproterozoic?) - Gray and dark-gray, fine- to medium-grained, weakly to strongly foliated, mostly equigranular quartz diorite, granodiorite, and monzogranite. Ratio of plagioclase (oligoclase or andesine) to microcline variable; rock contains 22-30 percent quartz, 30-40 percent plagioclase, 0-40 percent microcline, 6-12 percent biotite, and trace zircon, apatite, and opaque minerals. In places, rock has thin (typically 5-10 mm thick) light and dark layers ("ribbony" texture) due to variable biotite content. Generally correlates with Paleoproterozoic Kroenke Granodiorite of Barker and Brock (1965) in the Mount Harvard 15-minute quadrangle to the west. One area, in southwestern corner of quadrangle, interlayered with and grades into migmatitic biotite gneiss $(\mathrm{Xb})$ with indistinct contact; igneous component interpreted to have injected into biotite gneiss. New mean ${ }^{207} \mathrm{~Pb} /{ }^{206} \mathrm{~Pb}$ age for Kroenke Granodiorite, collected west of quadrangle, is 1,694 $\pm 12 \mathrm{Ma}$ (Moscati and others, 2012), but unit not called Kroenke Granodiorite in quadrangle due to uncertainty of this correlation 


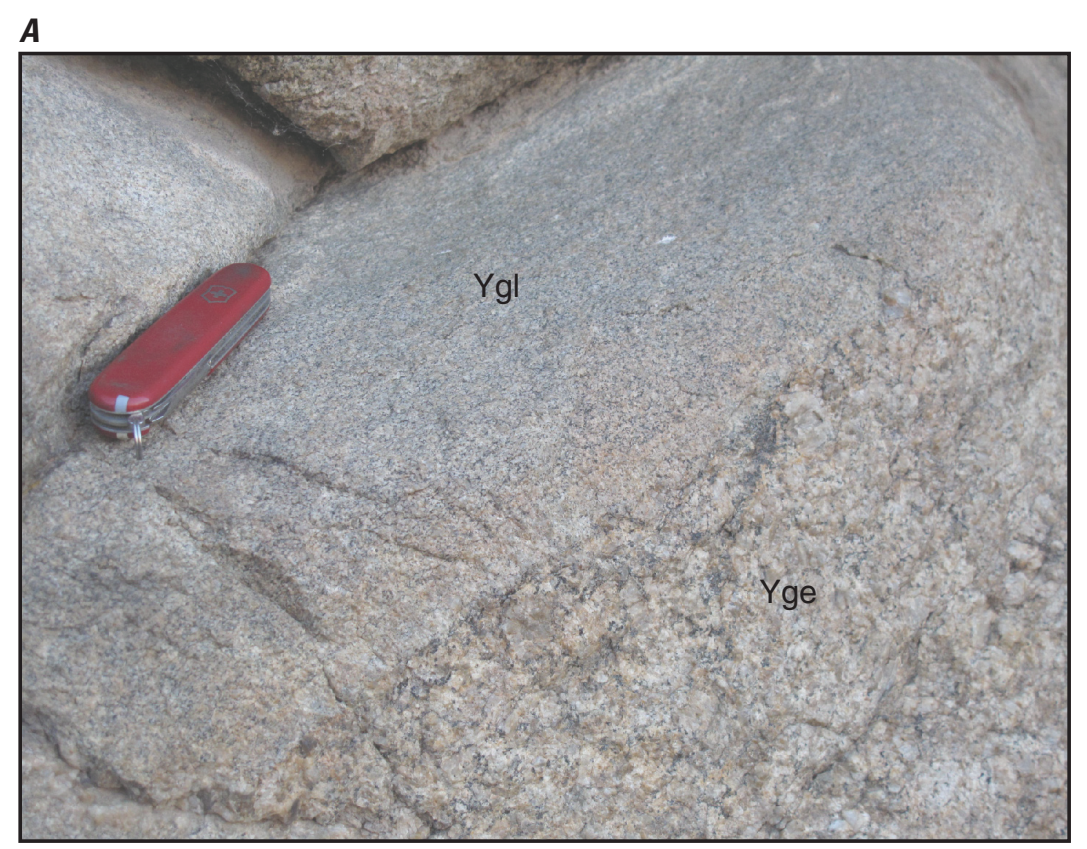

$B$

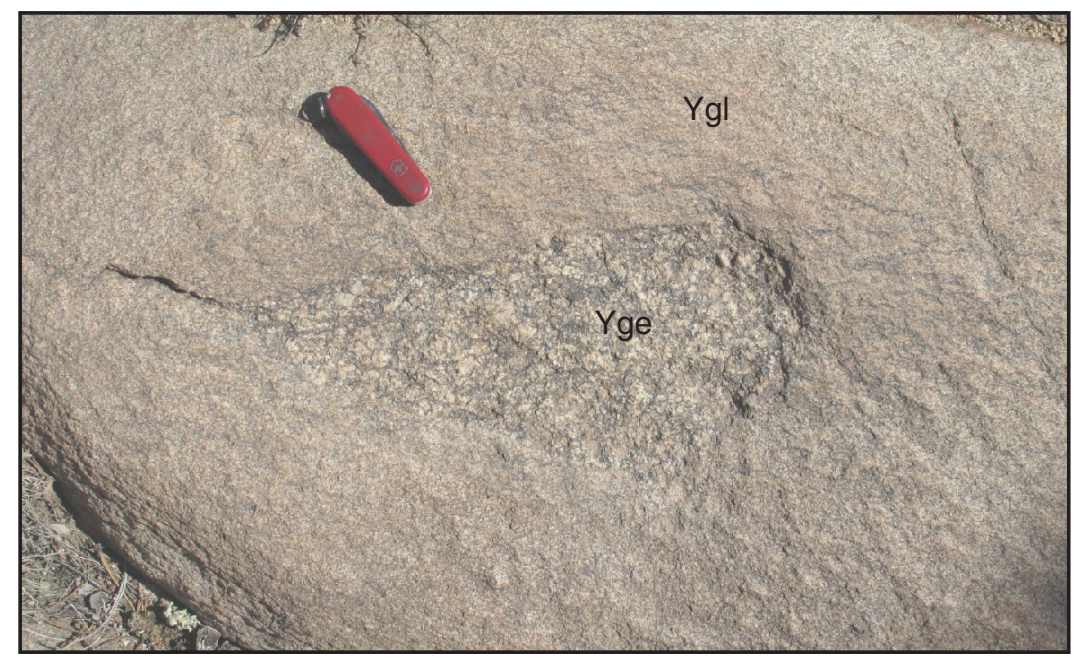

Figure 4. A, Contact of granite of Langhoff Gulch (Ygl) intruding weakly foliated granite of Elephant Rock (Yge). Small 1.5-cm-thick, more felsic, slightly earlier phase of Ygl forms layer along contact. $B$, Inclusion of granite of Elephant rock (Yge) enclosed in granite of Langhoff gulch (Ygl). Knife for scale is $9 \mathrm{~cm}$ long.

Diorite (Paleoproterozoic) - Dark-gray to gray, medium-grained, equigranular, massive to moderately foliated, biotite quartz diorite and biotite diorite. Contains as much as 40 percent biotite and a few percent hornblende. Crops out in two small areas in Clear Creek near western border of quadrangle

Biotite gneiss (Paleoproterozoic) - Mostly gray to dark-gray, fine- to medium-grained, moderately foliated to strongly foliated and layered gneiss. Migmatitic in most places; contains numerous light-colored layers and lenses (leucosomes) typically $0.1-10 \mathrm{~cm}$ thick, although locally may be much thicker. In most cases, leucosome bodies form less than half of rock, have sharp contacts with host rock, show much pinch and swell, and in some places are strongly folded. Leucosomes are composed of equigranular, massive to weakly foliated, white to light-gray microcline-plagioclase-quartz rock containing less than 5 percent biotite; accessory minerals are muscovite, opaque minerals, sphene, apatite, garnet, and zircon. Formation of leucosome 


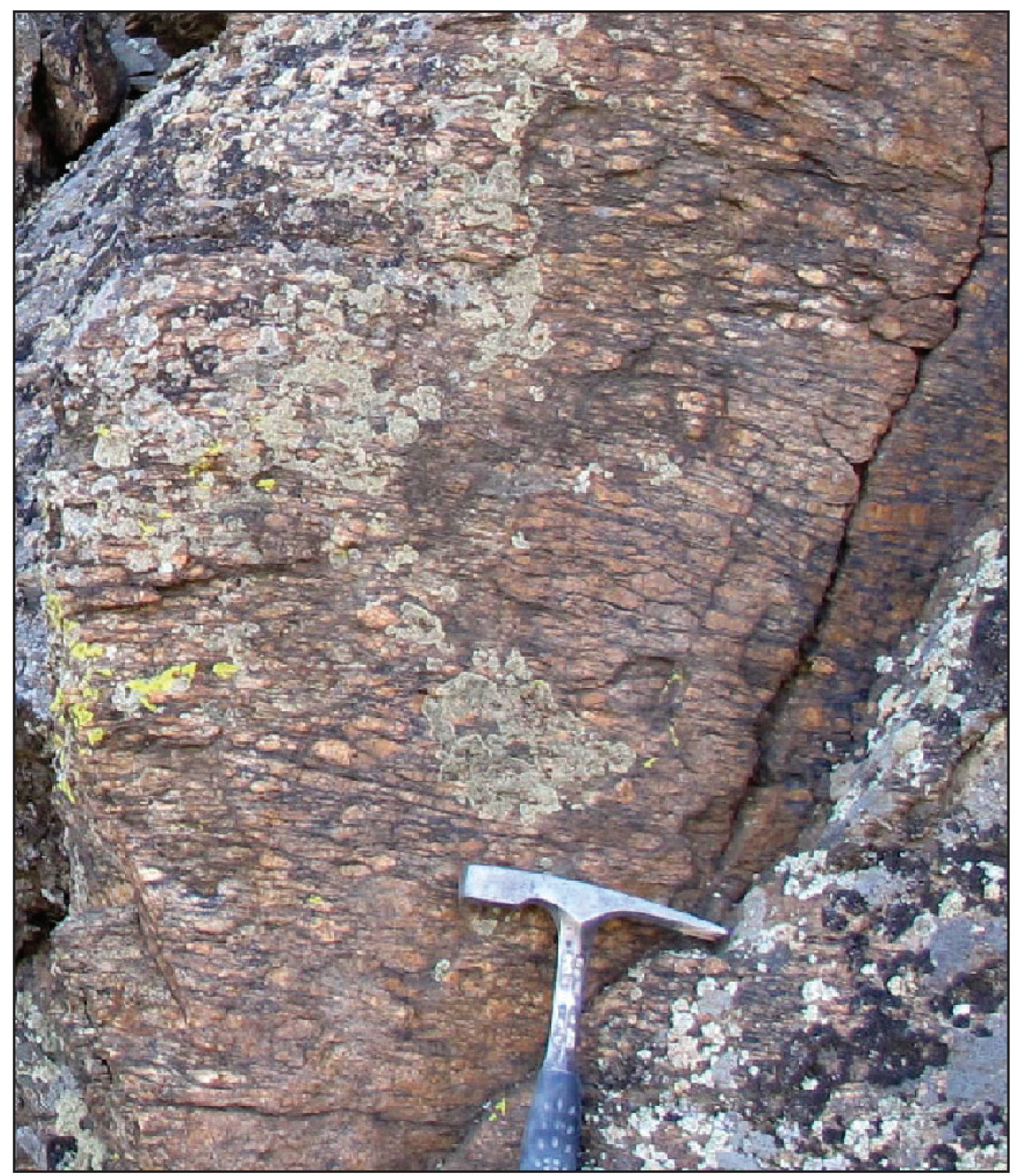

Figure 5. Strongly foliated augen gneiss formed from highly strained granite of Elephant Rock (Yge). Strike/dip of foliation is 080/20. View is to the south. Hammer head is $12 \mathrm{~cm}$ long.

may be due to either injection or in-situ partial melting (anatexis) (Olsen, 1982; Johannes and Gupta, 1982). In the latter case, biotite gneiss adjacent to leucosome commonly has biotite-rich selvages representing refractory material remaining from partial melting. Commonly injected by and interlayered with mediumgrained biotite granodiorite or granite (foliated granodiorite or Kroenke Granodiorite). Mapped in southwest corner of quadrangle, and in one small outcrop surrounded by younger till of Bull Lake glaciation in northwest corner of quadrangle. Unit undated in quadrangle, but similar rocks in the Gore Range and western Front Range northeast of the map area, have a U-Pb zircon melanosome age of about 1,785-1,740 Ma (Kellogg and others, 2011), which represents the age of the source rocks from which detritus that comprises sedimentary protolith was derived, so this age range represents the maximum depositional age of the protolith sediment

Xhg Hornblende-biotite gneiss (Paleoproterozoic) —Black, medium-grained, equigranular, strongly foliated hornblende-biotite gneiss. Hornblende + biotite comprises about 60 percent of rock; no visible quartz in hand sample. One recognized occurrence in 20-m-wide zone on south side of east-trending fault, east of Arkansas River opposite mouth of Morrison Creek. Rock sheared parallel to fault. Interpreted as large mafic inclusion within intermixed granite of Langhoff Gulch and granite of Elephant Rock (Yhy) exploited by Phanerozoic movement on fault, so shearing is probably Late Cretaceous or younger 


\section{Acknowledgments}

Mike Zawaski of Front Range Community College, Boulder, Colorado, assisted the first author in the field during the summers of 2010 and 2011. The authors would like to thank Cal Ruleman and Marieke Dechesne for reviews that significantly improved the report, especially the map and explanation. Kristi Zellman and Paco VanSistine carried out the GIS and graphics editing, and Theodore R. Brandt prepared the digital topographic base. L.J. Binder's edits greatly improved the map and text.

\section{References Cited}

Aleinikoff, J.N., Reed, J.C., Jr., and Wooden, J.L., 1993, Lead isotopic evidence for the origin of Paleo- and Mesoproterozoic rocks of the Colorado Province, U.S.A.: Precambrian Research, v. 63, p. 97-122.

Barker, Fred, and Brock, M.R., 1965, Denny Creek Granodiorite gneiss, Browns Pass quartz monzonite, and Kroenke granodiorite, Mount Harvard quadrangle, Colorado, in Cohee, G.V., and West, W.S., eds., Changes in stratigraphic nomenclature by the U.S. Geological Survey, 1964: U.S. Geological Survey Bulletin 1224-A, p. A23-A26.

Benson, Larry, Madole, Richard, Landis, Gary, and Gosse, John, 2005, New data for late Pleistocene alpine glaciation from southwestern Colorado: Quaternary Science Reviews, v. 24 , p. $46-65$.

Benson, Larry, Madole, Richard, Phillips, William, Landis, Gary, Thomas, Terry, and Kubic, Peter, 2004, The probable importance of snow and sediment shielding on cosmogenic ages of north-central Colorado Pinedale and pre-Pinedale moraines: Quaternary Science Reviews, v. 23, p. 193-206.

Bickford, M.E., and Hill, B.M., 2007, Does the arc accretion model adequately explain the Paleoproterozoic evolution of southern Laurentia? An expanded interpretation: Geology, v. 35 , p. $167-170$.

Bickford, M.E., Mueller, P.A., Kamenov, G.D., and Hill, B.M., 2008, Crustal evolution of southern Laurentia during the Paleoproterozoic - Insights from zircon Hf isotopic studies of ca. 1.75 Ga rocks in central Colorado: Geology, v. 36, p. $555-558$.

Bickford, M.E., Schuster, R.D., and Boardman, S.J., 1989, $\mathrm{U}-\mathrm{Pb}$ geochronology of the Proterozoic volcano-plutonic terrane in the Gunnison and Salida areas, Colorado, in Grambling, J.A., and Tewksbury, B.J., eds., Proterozoic geology of the southern Rocky Mountains: Geological Society of America Special Paper 235, p. 33-48.
Bickford, M.E., Van Schmus, W.R., and Zietz, I., 1986, Proterozoic history of the mid- continent region of North America: Geology, v. 14, p. 492-496.

Briner, J.P., 2009, Moraine pebbles and boulders yield indistinguishable ${ }^{10} \mathrm{Be}$ ages - A case study from Colorado, USA: Quaternary Geochronology, v. 4, p. 299-305.

Brock, M.R., and Barker, Fred, 1972, Geologic map of the Mount Harvard quadrangle, Chaffee and Gunnison Counties, Colorado: U.S. Geological Survey Geologic Quadrangle Map GQ-952, scale 1:62,500.

Brugger, K.A., 2007, Cosmogenic ${ }^{10} \mathrm{Be}$ and ${ }^{36} \mathrm{Cl}$ ages from Late Pleistocene terminal moraine complexes in the Taylor river drainage basin, central Colorado, USA: Quaternary Science Reviews, v. 26, p. 494-499.

Chadwick, O.A., Hall, R.D., and Phillips, F.M., 1997, Chronology of Pleistocene glacial advances in the central Rocky Mountains: Geological Society of America Bulletin, v. 109 , p. 1443-1452.

Chamberlain, K.R., 1998, Medicine Bow orogeny_-Timing of deformation and model of crustal structure produced during continental-arc collision, ca. $1.78 \mathrm{Ga}$, southeastern Wyoming: Rocky Mountain Geology, v. 33, no. 2, p. 259-277.

Chapin, C.E., 1979, Evolution of the Rio Grande Rift—A summary, in Riecker, R.E., ed., Rio Grande rift: tectonics and magmatism: Washington, D.C., American Geophysical Union, p. 1-6.

Chapin, C.E., and Cather, S.M., 1994, Tectonic setting of the axial basins of the northern and central Rio Grande rift, in Keller, G.R., and Cather, S.M., eds., Basins of the Rio Grande Rift-Structure, stratigraphy, and tectonic setting: Geological Society of America Special Paper 291, p. 5-25.

Cruden, D.M., and Varnes, D.J., 1996, Landslide types and processes, in Turner, A.K., and Schuster, R.L., eds., Landslides investigation and mitigation: Washington, D.C., National Academy Press, p. 36-75.

DeWitt, E.H., Premo, W.R., and Klein, T.L., 2010, The Early Proterozoic Poudre Basin, an important constraint on 1.77-1.73-Ga tectonic events in western Colorado [abs.]: Geological Society of America Abstracts with Programs, v. 42 , no. 5 , p. 654 .

Fridrich, C.J., DeWitt, E.H., Bryant, Bruce, Richard, Steve, and Smith, R.P., 1998, Geologic map of the Collegiate Peaks Wilderness area and the Grizzly Peak caldera, Sawatch Range, Colorado: U.S. Geological Survey Miscellaneous Investigations Series I-2565, scale 1:50,000.

Guido, Z.S., Ward, D.J., and Anderson, R.S., 2007, Pacing the post-Last Glacial Maximum demise of the Animas Valley glacier and the San Juan Mountains ice cap, Colorado: Geology, v. 35, no. 8, p. 739-742. 
Hedlund, D.C., 1985, Geologic map of the Buffalo Peaks Wilderness Study Area, Lake, Park, and Chaffee Counties, Colorado: U.S. Geological Survey Miscellaneous Field Studies Map MF-1628-C, scale 1:50,000.

Hill, B.M., and Bickford, M.E., 2001, Paleoproterozoic rocks of central Colorado: Accreted arcs or extended older crust?: Geology, v. 29, p. 1015-1018.

Houck, K.J., Funk, J.A., Kirkham, R.M., Carroll, C.J., and Heberton-Morimoto, A.D., 2012, Marmot Peak quadrangle geologic map, Park and Chaffee Counties, Colorado: Colorado Geological Survey Open-File Map 12-1, scale 1:24,000.

Izett, G.A., 1968, Geology of the Hot Sulphur Springs quadrangle, Grand County, Colorado: U. S. Geological Survey Professional Paper 586, 79 p, 1 pl., scale 1:62,500.

Johannes, W., and Gupta, L.N., 1982, Origin and evolution of a migmatite: Contributions to Mineralogy and Petrology, v. 79, p. 114-123.

Kellogg, K.S., Bryant, Bruce, and Reed, J.C., Jr., 2004, The Colorado Front Range-Anatomy of a Laramide uplift, in Nelson, E.P., and Erslev, E.A., eds., Field trips in the southern Rocky Mountains, USA: Geological Society of America Field Guide 5, p. 89-108.

Kellogg, K.S., Shroba, R.R., Bryant, Bruce, and Premo, W.R., 2008, Geologic map of the Denver West 30' $\times 60^{\prime}$ quadrangle, Colorado: U.S. Geological Survey Scientific Investigations Map 3000, scale 1:100,000.

Kellogg, K.S., Shroba, R.R., Premo, W.R., and Bryant, Bruce, 2011, Geologic map of the eastern half of the Vail $30^{\prime} \times 60^{\prime}$ quadrangle, Eagle, Summit, and Grand Counties, Colorado: U.S. Geological Survey Scientific Investigations Map 3170, 49-p. pamphlet, scale 1:100,000.

Keller, J.W., McCalpin, J.P., and Lowry, B.W., 2004, Geologic map of the Buena Vista East quadrangle, Chaffee County, Colorado: Colorado Geological Survey Open-File Report 04-4, scale 1:24,000.

Lanphere, M.A., Champion, D.E., Christiansen, R.L., Izett, G.A., and Obradovich, J.D., 2002, Revised ages for tuffs of the Yellowstone Plateau volcanic field-Assignment of the Huckleberry Ridge Tuff to a new geomagnetic polarity event: Geological Society of America, v. 114, p. 559-568.

Lee, Keenan, 2010, Catastrophic glacial outburst floods on the Arkansas River, Colorado: The Mountain Geologist, v. 47, no. 2 , p. $35-57$.

Licciardi, J.M., and Pierce, K.L., 2008, Cosmgenic exposureage chronologies of Pinedale and Bull Lake glaciations in greater Yellowstone and the Teton Range, USA: Quaternary Science Reviews, v. 27, p. 814-831.
Lisiecki, L.E., Raymo, M.E., 2009, Diachronous benthic $\delta^{18} \mathrm{O}$ responses during late Pleistocene terminations: Paleoceanography, v. 24, p. 1-14.

Madole, R.F., 1986, Lake Devlin and Pinedale glacial history, Front Range, Colorado: Quaternary Research, v. 25, p. 43-54.

Marvin, R.F., Mehnert, H.H., Naeser, C.W., and Zartman, R.E., 1989, U.S. Geological Survey radiometric ages compilation C-Part five; Colorado, Montana, Utah, and Wyoming: Isochron/West, no. 53, p. 14-19.

Mears, Brainerd, Jr., 1998, Neogene faulting superposed on a Laramide uplift—Medicine Bow Mountains, Sierra Madre, and intervening Saratoga Valley, Wyoming and Colorado: Laramie, University of Wyoming, Contributions to Geology, v. 32, p. 181-185.

McCalpin, J.P., Funk, Jonathan, and Mendel, David, 2012, Leadville South quadrangle, Lake County, Colorado: Colorado Geological Survey, scale 1:24,000. Available at http://geosurveystore.state.co.us/p-1360-leadville-southquadrangle-lake-county-colorado.aspx.

McCalpin, J.P., and Shannon, J.R., 2005, Geologic map of the Buena Vista West quadrangle, Chaffee County, Colorado: Colorado Geological Survey Open-File Report 05-8, scale $1: 24,000$.

McIntosh, W.C., and Chapin, C.E., 2004, Geochronology of the central Colorado volcanic field, in Cather, S.M., McIntosh, W.C., and Kelley, S.A., eds., Tectonics, geochronology, and volcanism in the southern Rocky Mountains and Rio Grande rift: New Mexico Bureau of Geology and Mineral Resources Bulletin 160, p. 205-237.

Moscati, R.J., Premo, W.R., and DeWitt, E.H., 2012, SHRIMP-RG U-Pb geochronology and trace element geochemistry of zircons from Proterozoic granitic plutons in the Sawatch Range, Colorado, USA [abs.]: Geological Society of America Abstracts with programs, v. 44, no. 7, p. 234.

Myrow, P.M., Taylor, J.F., Miller, J.F., Ethington, R.L., Ripperton, R.L., and Allen J., 2003, Fallen arches-Dispelling myths concerning Cambrian and Ordovician paleogeography of the Rocky Mountain region: Geological Society of America, v. 115, no. 6, p. 695-713.

Nelson, A.R., Millington, A.C., Andrews, J.T., and Nichols, H., 1979, Radiocarbon-dated upper Pleistocene glacial sequence, Fraser Valley, Colorado Front Range: Geology, v. 7, p. $410-414$.

Olsen, S.N., 1982, Open- and closed-system migmatites in the Front Range, Colorado: American Journal of Science, v. 282 , p. $1596-1622$. 
Pierce, K.L., 2004, Pleistocene glaciation of the Rocky Mountains, in Gillespie, A.R., Porter, S.C., and Atwater, B.F., eds., The Quaternary Period in the United States: Amsterdam, Elsevier Science, p. 63-76.

Premo, W.R., Kellogg, K.S., Bryant, Bruce, 2007, SHRIMP $\mathrm{U}-\mathrm{Pb}$ zircon ages for Paleoproterozoic basement rocks from the northern and central Colorado Front Range-A refinement of the timing of crustal growth in the Colorado Province [abs.]: Geological Society of America Abstracts with Programs, v. 39, no. 6, p. 221.

Reed, J.C., Jr., Bickford, M.E., and Tweto, Ogden, 1993, Proterozoic accretionary terranes of Colorado and southern Wyoming, in Reed, J.C., Jr., and six others, eds., Precambrian Conterminous U.S.: Geological Society of America, The geology of North America, v. C-2, p. 211-228.

Sanders, G.F., Jr., 1975, Geology of the Buffalo Peaks, Park and Chaffee Counties Colorado: Golden, Colo., Colorado School of Mines, Master's thesis, T-1731, 62 p., 2 pl.

Sanford, A.R., Olsen, K.H., and Jaksha, L.H., 1979, Seismicity of the Rio Grande Rift, in Riecker, R.E., ed., Rio Grande rift-Tectonics and magmatism: Washington, D.C., American Geophysical Union, p. 145-168.

Sarna-Wojcicki, A.M., Pringle, M.S., and Wijbrans, Jan, 2000, New ${ }^{40} \mathrm{Ar} /{ }^{39} \mathrm{Ar}$ age of the Bishop Tuff from multiple sites and sedimentation rate calibration of the MatuyamaBrunhes boundary: Journal of Geophysical Research, v. 105 , p. 21431-21443.

Schildgen, Taylor, Dethier, D.P., Bierman, Paul, and Caffee, Marc, 2002, ${ }^{26} \mathrm{Al}$ and ${ }^{10} \mathrm{Be}$ dating of late Pleistocene and Holocene fill terraces - A record of fluvial deposition and incision, Colorado Front Range: Earth Surface Process and Landforms, v. 27, p. 773-787.

Scott, G.R., 1975, Reconnaissance geologic map of the Buena Vista quadrangle, Chaffee and Park Counties, Colorado: U.S. Geological Survey Miscellaneous Field Studies Map MF-657, scale 1:62,500.

Publishing support provided by:

Denver Publishing Service Center, Denver, Colorado

For more information concerning this publication, contact:

Center Director, USGS Geosciences and Environmental Change Science Center Box 25046, Mail Stop 980

Denver, CO 80225

(303) 236-5344

Or visit the Geosciences and Environmental Change Science Center Web site at: http://gec.cr.usgs.gov/

This publication is available online at: http://dx.doi.org/10.3133/sim3267
Sharp, W.D., Ludwig, K.R., Chadwick, O.A., Amundson, Ronald, and Glaser, L.L., 2003, Dating fluvial terraces by ${ }^{230} \mathrm{Th} / \mathrm{U}$ on pedogenic carbonate, Wind River basin, Wyoming: Quaternary Research, v. 59, p. 139-150.

Shroba, R.R., Rosholt, J.N., and Madole, R.F., 1983, Uraniumtrend dating and soil B horizon properties of till of Bull Lake age, North St. Vrain drainage basin, Front Range, Colorado [abs.]: Geological Society of America Abstracts with Programs, v. 15, no. 5, p. 431.

Thompson, R.A., Johnson, C.M., and Mehnert, H.H., 1991, Oligocene basaltic volcanism of the northern Rio Grande Rift, San Luis Hills, Colorado: Journal of Geophysical Research, v., 96, no. B8, p. 13557-13592.

Tweto, Ogden, 1975, Laramide (Late Cretaceous-Early Tertiary) orogeny in the Southern Rocky Mountains, in Curtis, B.F., ed., Cenozoic history of the Southern Rocky Mountains: Geological Society of America Memoir 144, p. 1-44.

Tweto, Ogden, 1979, The Rio Grande rift system in Colorado, in Riecker, R.E., ed., Rio Grande rift-Tectonics and magmatism: Washington, D.C., American Geophysical Union, p. 33-56.

Tweto, Ogden, 1987, Rock units of the Precambrian basement in Colorado: U.S. Geological Survey Professional Paper 1321-A, $54 \mathrm{p}$.

Widmann, B.L., Kirkham, R.M., Houck, K.J., and Lindsay, N.R., 2011, Geologic map of the Jones Hill quadrangle, Park County, Colorado: Colorado Geological Survey OpenFile Report 07-5, scale 1:24,000.

Young, N.E., Briner, J.P, Leonard, E.M., Licciardi, J.M., and Lee, Keenan, 2011, Assessing climatic and nonclimatic forcing of Pinedale glaciation and deglaciation in the western US: Geology, v. 39, no. 2, p. 171-174. 


\section{$\frac{\mathbb{2}}{3}$}

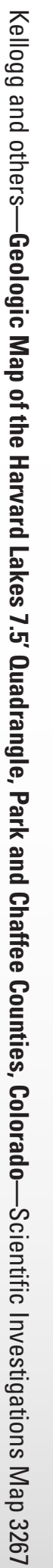

